Georgetown University Law Center

Scholarship @ GEORGETOWN LAW

2021

\title{
Citizens, Suspects, and Enemies: Examining Police Militarization
}

Milton C. Regan

Georgetown University Law Center, regan@law.georgetown.edu

This paper can be downloaded free of charge from:

https://scholarship.law.georgetown.edu/facpub/2346

https://ssrn.com/abstract=3772930

Texas National Security Review, Winter 2020/2021.

This open-access article is brought to you by the Georgetown Law Library. Posted with permission of the author. Follow this and additional works at: https://scholarship.law.georgetown.edu/facpub

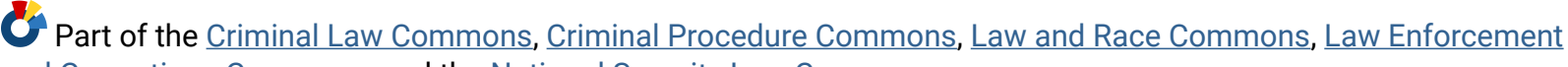
and Corrections Commons, and the National Security Law Commons 


\title{
Citizens, Suspects, and Enemies: Examining Police Militarization
}

\author{
Mitt Regan
}

\begin{abstract}
Concern about the increasing militarization of police has grown in recent years. Much of this concern focuses on the material aspects of militarization: the greater use of military equipment and tactics by police officers. While this development deserves attention, a subtler form of militarization operates on the cultural level. Here, police adopt an adversarial stance toward minority communities, whose members are regarded as presumptive objects of suspicion. The combination of material and cultural militarization in turn has a potential symbolic dimension. It can communicate that members of minority communities are threats to society, just as military enemies are threats to the United States. This conception of racial and ethnic minorities treats them as outside the social contract rather than as fellow citizens. It also conceives of the role of police and the military as comparable, thus blurring in a disturbing way the distinction between law enforcement and national security operations.
\end{abstract}

Demonstrations in recent years following the deaths of African Americans, especially African American men, at the hands of police have raised fundamental issues about race and criminal justice in the United States. Central to these demonstrations is concern about the use of force by the state against its own citizens. ${ }^{1}$ One prominent way in which this is expressed is the claim that there is a trend toward the "militarization" of the police in America, in particular, the use of military tactics and equipment by police and the acquisition of such equipment through programs such as the one administered by the Department of Defense. This concern reflects unease about what I call the "material" dimension of militarization. The risk posed by this dimension is physical: that police will use intense violence against individuals and communities to secure order. Police officers should not act like soldiers because soldiers are authorized to use especially destructive means to secure their objectives, means that the police should not be permitted to use.

Apprehension about the police becoming more militarized is reflected even more directly in the objection to the use of military forces to respond to public demonstrations, as President Donald Trump has suggested is necessary to quell some of the recent protests

\footnotetext{
${ }^{1}$ By "citizens," I mean to include all persons in the United States who may be subject to the use of force, regardless of their legal status. I use the term both for shorthand convenience and to highlight the issues in political theory that I will be discussing.
} 
against police violence. ${ }^{2}$ Criticism of this suggestion has been widespread, including from prominent former military leaders. ${ }^{3}$ As former Secretary of Defense Gen. (Ret.) James Mattis declared, referring to language used by then-Secretary of Defense Mark Esper, "We must reject any thinking of our cities as a 'battlespace' that our uniformed military is called upon to 'dominate."'4 Criticism of police militarization and of using the military to secure public order thus reflects the same underlying concern.

Conceiving of the difference between the police and the military in terms of the level of violence each can inflict calls attention to an important risk that militarized police can pose. There is a subtler dimension of militarization, however, which I call its "cultural" dimension. This involves how police officers approach the communities in which they work as well as public perceptions of the proper relationship between the police and these communities. As I suggest in this article, cultural militarization reflects an orientation in which police regard their relationship with certain communities as adversarial, and members of those communities as criminal suspects. In its extreme form, police work becomes akin to deployment in warfare, wherein citizens become enemies rather than fellow members of the community. This form of militarization is not reflected simply in weapons and tactics, but in attitudes and habits of mind.

Appreciating this dimension of militarization underscores that police should not act like soldiers because police are meant to protect citizens against criminals, while soldiers protect citizens against enemies. Criminals are deviants within the community. Enemies are outside the social contract and thus are not entitled to the kind of concern that fellow citizens deserve. Police treatment of certain groups of citizens as enemies threatens to erase this distinction and to blur the roles of the police and the military. It also has a symbolic political dimension in that it communicates to the larger public that certain citizens are outside the social contract and thus are not deserving of the benefits of full citizenship. Such a message threatens the very foundations of a liberal democracy. This is the fundamental danger of police militarization. As this paper will describe, there is reason to believe that this type of militarization is occurring, as evidenced by how police deal with minority communities.

This article draws on empirical research on policing in America in recent years to describe the ways in which police operations in some minority communities blur the line between the police and the military. The work in this field includes research on both the material and cultural dimensions of militarization. These studies help clarify that concern

\footnotetext{
2 The president has declared that, "if a city or state refuses to take the actions necessary to defend the life and property of their residents, then I will deploy the United States military and quickly solve the problem for them." Steve Herman, "Trump Threatens Wide Use of Military Force Against Protesters," Voice of America, June 2, 2020, https://www.voanews.com/usa/trump-threatens-wide-use-military-force-against-protesters. ${ }^{3}$ Zeke Miller and Robert Burns, "Pentagon-Trump Clash Breaks Open Over Military and Protests," ABC News, June 4, 2020, https://apnews.com/article/3a49cd9ff99b98b4cd9e55c9364e6574.

4 “Former Defense Secretary Mattis' Statement on Trump and Protests," CNN, June 3, 2020, https://www.cnn.com/2020/06/03/politics/mattis-protests-statement/index.html.
} 
about police militarization reflects not simply anxiety about the physical effects of militarization, but a deeper concern about distinguishing between different state agents who are authorized to use force in different ways to provide security for citizens in a liberal democracy.

Policing scholar Peter Kraska defines police militarization as "the process whereby civilian police increasingly draw from, and pattern themselves around, the tenets of militarism and the military model." ${ }^{5} \mathrm{He}$ describes militarism as "a set of beliefs, values, and assumptions that stress the use of force and threat of violence as the most appropriate and efficacious means to solve problems." 6 Kraska suggests that there are four dimensions of militarization: (1) material, reflected in greater use of military equipment; (2) cultural, involving the adoption of military beliefs and values; (3) organizational, as evidenced, for example, by the use of paramilitary units modeled on military special operations forces; and (4) operational, reflected in aggressive preventive patrolling. ${ }^{7}$ He acknowledges that there has always been some military influence on policing, since, like the military, police are authorized to use force if necessary to achieve their objectives. ${ }^{8}$ Since militarization is, therefore, a matter of degree, the relevant question is "where the civilian police fall on the continuum and in what direction they are headed." 9

With about 18,000 law enforcement agencies in the United States, it can be misleading to make sweeping statements about the "police." 10 Individual agencies are likely to differ in various ways, including the extent to which they are militarized. Nonetheless, trends in the law enforcement community appear to indicate that many agencies are moving in a common direction. My goal in this article is to examine whether this is occurring, whether it is contributing to more effective law enforcement, and what its broader impacts might be. Only by engaging with empirical research can we fully understand police militarization.

\footnotetext{
${ }^{5}$ Peter B. Kraska, "Militarization and Policing - Its Relevance to 21st Century Police," Policing 1, no. 4 (2007): 503, https://doi.org/10.1093/police/pam065.

${ }^{6}$ Kraska, "Militarization and Policing," 503. Kraska has written extensively on police militarization since the 1990s. Peter B. Kraska and Shannon Williams, "The Material Reality of State Violence: The Case of Police Militarization," in The Routledge International Handbook of Violence Studies, ed. Walter S. DeKeseredy, Callie Marie Rennison, and Amanda K. Hall-Sanchez (New York: Routledge, 2019).

${ }^{7}$ Kraska, "Militarization and Policing," 503.

${ }^{8}$ In addition, William Allison has noted that reformers around the turn of the 20th century drew on the military metaphor in their campaign to eliminate corruption and professionalize local police forces. See, William Thomas Allison, "The Militarization of American Policing: Enduring Metaphor for a Shifting Context," in Uniform Behavior: Police Localism and National Politics, ed. Stacy McGoldrick and Andrea McArdle (New York: Palgrave McMillan, 2006), 9.

${ }^{9}$ Kraska, "Militarization and Policing," 504.

${ }^{10}$ National Sources of Law Enforcement Employment Data, U.S. Department of Justice, April 2016, revised Oct. 4, 2016, https://www.bjs.gov/content/pub/pdf/nsleed.pdf.
} 
We can gain insight into police militarization by slightly reframing Kraska's typology to focus on just the cultural and material dimensions, and to add a third dimension: the symbolic. The symbolic dimension focuses on the message that cultural and material militarization send about the relationship between the state and its citizens in a liberal democracy.

The first section of this article discusses how an increasing use of military metaphors, an uptick in what I call aggressive preventive policing, and reliance on more heavily armed patrol officers all reflect a subtle cultural shift toward a more adversarial relationship between many police departments and the communities they serve, especially in minority communities. The second section examines the material dimension of militarization, which involves expanded use of police paramilitary units and military equipment. These two dimensions can mutually reinforce one another: The cultural dimension can make the use of military tactics and weapons seem more appropriate and normal, while the availability of military equipment may subtly incline those who have access to them to use them. Section three explores how the combination of cultural and material militarization generates a symbolic dimension. This dimension can signal that certain members of the community - especially members of minority communities - are outside the social contract and thus are potential enemies. From this perspective, just as the military protects citizens from external enemies, the police protect them from internal ones.

In the conclusion, I suggest that developments in these three dimensions reflect an intensification of police militarization in recent years in many minority communities. ${ }^{11}$ The two primary dimensions of militarization raise distinctive concerns: Cultural militarization makes the relationship between police and minority communities more adversarial as police who regard themselves as crime fighters aggressively seek out suspects. Material militarization increases the intensity of the violence that police have available to them in pursuing these suspects.

Appreciation of these complex aspects of police militarization helps clarify the respective roles of the police and the military in keeping the citizenry secure and the danger in blurring them. It also suggests that it may be time to rethink how America attempts to secure domestic public safety. Former Secretary of Defense Robert Gates has criticized what he calls the "overmilitarization" of U.S. foreign policy, which neglects tools

\footnotetext{
${ }^{11}$ For a deeper discussion on race, policing, and criminal justice, see generally, Michelle Alexander, The New Jim Crow: Mass Incarceration in the Age of Colorblindness (New York: The New Press, 2012); Paul Butler, Chokehold: Policing Black Men (New York: The New Press, 2018); James Forman, Jr., Locking Up Our Own: Crime and Punishment in Black America (New York: Farrar, Strauss and Giroux, 2017); Frank R. Baumgartner, Derek A. Epp, and Kelsey Shoub, Suspect Citizens: What 20 Million Traffic Stops Tell Us About Policing and Race (New York: Cambridge University Press, 2018); and Charles R. Epp, Steven Maynard-Moody, and Donald Haider-Markel, Pulled Over: How Police Stops Define Race and Citizenship (Chicago, IL: Chicago University Press, 2014).
} 
such as diplomacy and economic assistance in enhancing external security. ${ }^{12}$ There is reason to believe that there has been an overmilitarization of the task of ensuring internal security as well.

More generally, increasing police militarization creates the risk that policing in minority communities will be seen not as law enforcement, but as national security operations against domestic enemies of the United States. There are aspects of domestic policing that do have a national security dimension, but daily interaction between police and racial and ethnic minorities should not be regarded as one of these. To treat it as such opens the door to more expansive use of force and greater restrictions on liberty than should be accepted in ordinary law enforcement. Aside from the concrete consequences for minority community members, this conception of police operations threatens to weaken the integrity of the very concept of national security, thereby distorting our understanding of what count as genuine national security concerns.

\section{THE CULTURAL DIMENSION OF MILITARIZATION}

\section{The Police and the Military}

In assessing the extent to which police adopt a military perspective, it is helpful to clarify the role of these two state agents. Donald Campbell and Kathleen Campbell write that the traditional description of the role of police is to "protect and serve" the community, ${ }^{13}$ while Arthur Rizer suggests that the mission of the police is to "keep the peace."14 Under these definitions, the police ought to avoid using violence unless it is unavoidable. ${ }^{15}$ By contrast, the military is responsible for protecting the state from external enemies. According to Rizer, military personnel "are trained to identify people they encounter as belonging to one of two groups — the enemy and the non-enemy - and they often reach this decision while surrounded by a population that considers the soldier an occupying force."16 In such situations, military forces must look upon the local population

\footnotetext{
12 Robert M. Gates, "The Overmilitarization of American Foreign Policy," Foreign Affairs 99, no. 4 (July/August 2020): 121, https://www.foreignaffairs.com/articles/united-states/2020-06-02/robert-gatesovermilitarization-american-foreign-policy.

${ }^{13}$ Donald J. Campbell and Kathleen M. Campbell, "Soldiers as Police Officers/Police Officers as Soldiers: Role Evolution and Revolution in the United States," Armed Forces \& Society 36, no. 2 (2010): 327, https://doi.org/10.1177\%2F0095327X09335945.

${ }^{14}$ Arthur Rizer and Joseph Hartman, "How the War on Terror Has Militarized the Police," The Atlantic, Nov. 7, 2011, https://www.theatlantic.com/national/archive/2011/11/how-the-war-on-terror-has-militarized-thepolice $/ 248047 /$.

15 This will be reflected in domestic law, as informed by basic human rights principles. For the latter, see, "Basic Principles on the Use of Force and Firearms by Law Enforcement Officials," United Nations, Office of the High Command, 1990, https://www.ohchr.org/en/professionalinterest/pages/useofforceandfirearms.aspx.

${ }^{16}$ Rizer and Hartman, "How the War," 12.
} 
with suspicion, alert to the presence of enemies against whom they are authorized to use lethal force as a first resort. ${ }^{17}$

Campbell and Campbell suggest that the ideal types of police and military forces have three different orientations. With regard to their jobs, police "protect and prevent," while the military "overwhelm[s] and pacif[ies]."18 The frequency with which police use force is low and is treated as a last resort, while for the military use of force is high in that it is frequent and is treated as a first resort. Finally, the police ideally assume that their work environment is mostly benign, while the military assumes it is mostly hostile. ${ }^{19}$

These orientations reflect the fact that the police operate within the community they serve, and share a common concern with citizens for its welfare. Police help reinforce shared norms of behavior by protecting fellow citizens from other citizens who would violate these norms. In this respect, they stand within, not outside, the community and work with, not against, it to enable the peaceful co-existence of its members. By contrast, the military protects the community from outsiders. Its orientation is outward, not inward, as it stands guard against external enemies. In this sense, the military acts on behalf of, but not in collaboration with, those whose security it protects. The norms it follows in its operations are particular to this role and are distinct from the norms of ordinary life. Concern about police militarization, I will suggest, reflects anxiety that police increasingly are adopting this orientation toward those they serve, instead of seeing themselves as providing security through collaboration with fellow citizens.

Anxiety about a gulf between those who protect society and society itself dates back to the founding of the American republic. At that time, it took the form of fear that a standing professional army could become a group separate from ordinary citizens, and could thereby be used by officials to suppress them. The American colonists' experience with the British Army enforcing the law in the colonies led many colonial leaders to regard a standing army as less attuned and committed to shared republican values, and thus as a potential threat to government based on those values. They drew on the observations of British jurist William Blackstone who wrote, "Nothing ... ought to be more guarded against in a free state than making the military power ... a body too distinct from the people." 20 In this vein, John Adams and Thomas Jefferson criticized Oliver Cromwell's New Model Army, a novel professional force that had helped remove King Charles I from the throne and install Cromwell as Lord Protector, as "loyal not to an ideal or to a government but to a commander and to its own traditions." 21

\footnotetext{
17 See, "The Geneva Conventions and Their Commentaries," International Committee of the Red Cross, Jan. 1, 2014, https://www.icrc.org/en/war-and-law/treaties-customary-law/geneva-conventions.

${ }^{18}$ Campbell and Campbell, "Soldiers as Police Officers," 327-50.

${ }^{19}$ Campbell and Campbell, "Soldiers as Police Officers," 344.

${ }^{20}$ William Blackstone, Commentaries on the Laws of England, ed. Edward Christian, vol. I, ch. 13, 413 (1800).

${ }^{21}$ Quoted in Richard H. Kohn, Eagle and Sword: The Federalists and the Creation of the Military Establishment in America, 1783-1802 (New York: Free Press, 1975), 2.
} 
By contrast, for many American constitutional framers, a civilian militia would be comprised of people who would answer the call to defend the nation when necessary but would then return to their private affairs after having fulfilled this responsibility. ${ }^{22}$ This was seen as providing reassurance that the citizen-soldier would not use his weapons against his fellow citizens. As Alexander Hamilton argued, "What shadow of danger can there be from men who are daily mingling with the rest of their countrymen and who participate with them in the same feelings, sentiments, habits, and interests?" 23 This led anti-Federalists to propose that the defense of the country should be the primary responsibility of civilian militias in each state, which could be "called forth" periodically when the nation was threatened, rather than a permanent army. ${ }^{24}$

Their proposal did not prevail. Nevertheless, the debate highlights a basic underlying concern about those who are authorized to use force to protect the community. To be sure, the debate was based on the founders' experience with the British crown and the fear that the army could be used to undermine their democratic experiment and restore a monarchy. It was also shaped by concerns about reposing too much authority in a federal government at the expense of the states. Each concern, however, reflected a deeper worry that those responsible for the security of the community might not see themselves as fellow citizens mutually committed to the same norms and values.

Today, the civilian militia takes the form of state National Guard units, which can be federalized when the president deems appropriate. In the late-19th and early-20th centuries, local police gradually replaced civilian militias in keeping order in large cities, while state police emerged to do the same in rural areas. ${ }^{25}$ Police thus assumed the role of the militia in serving as members of the community, responsible for keeping it safe.

The fear that soldiers rather than police would be used for domestic law enforcement is reflected in the Posse Comitatus Act. The term is Latin for "power of the county," which refers to the tradition under which a county sheriff could mobilize citizens to suppress lawlessness or defend the county — that is, engage in local law enforcement. The act states, "Whoever, except in cases and under circumstances expressly authorized by the Constitution or Act of Congress, willfully uses any part of the Army or the Air Force as a posse comitatus or otherwise to execute the laws" is subject to fine and imprisonment. In

\footnotetext{
${ }^{22}$ Deborah N. Pearlstein, "The Soldier, the State, and the Separation of Powers," Texas Law Review, 90, no. 4 (2012): 797, 846, http://texaslawreview.org/wp-content/uploads/2015/08/Pearlstein-90-TLR-797.pdf. ${ }^{23}$ Alexander Hamilton, Federalist No. 29 in The Federalist Papers, ed. Clinton Rossiter (New York: Penguin Putnam, 1961), 186.

${ }^{24}$ Lawrence Delbert Cress, "Republican Liberty and National Security: American Military Policy as an Ideological Problem, 1783 to 1789," William and Mary Quarterly 38, no. 1 (January 1981): 73-96, https://doi.org/10.2307/1916858.

${ }_{25}$ Robert Reinders, "Militia and Public Order in Nineteenth-Century America," Journal of American Studies 11, no. 1 (April 1977): 81-101, https://doi.org/10.1017/S0021875800003388.
} 
recent years, Congress has authorized an increasing military role in aid of law enforcement efforts, such as drug interdiction. ${ }^{26}$ As reflected, however, in widespread criticism of Trump's claim that it is necessary to use the military to restore public order in the wake of demonstrations protesting police violence, there remains considerable resistance to using the military for direct law enforcement. ${ }^{27}$ This echoes the founders' concern that a professional military might be deployed against persons whom they regard not as fellow citizens but as enemies of the state. As Mattis said in criticizing Trump's actions, "Keeping public order rests with civilian state and local leaders who best understand their communities and are answerable to them." 28

A standing professional army has not turned out to pose the risk that the founders feared. We need to consider, however, whether this risk may be emerging from local police forces that are becoming more militarized. The remainder of this section discusses trends that suggest that this may be occurring, at least with respect to police relationships with many minority communities.

\section{The Metaphor of War}

Reliance on the metaphor of war is a prominent expression of cultural militarization. As David Davenport and Gordon Lloyd observe, over the last few decades the war metaphor has been "a powerful rhetorical tool that has shaped public policy. There are troops to muster, enemies to fight, and battles to win." 29 The claims that police are engaged in a "war on drugs" and a "war on terror" explicitly reflect a military orientation

\footnotetext{
${ }^{26}$ Stephen Dycus et al., National Security Law, 6th ed. (New York: Wolters-Kluwer, 2016), 1235-42.

27 On Trump's claim, see, Christina Wilkie and Amanda Macis, "Trump Threatens to Deploy Military as George Floyd Protests Continue to Shake the U.S.," CNBC, June 1, 2020, https://www.cnbc.com/2020/06/01/trumpthreatens-to-deploy-military-as-george-floyd-protests-continue-to-shake-the-us.html; and, "Trump Threatens Use Of Military On Protesters; George Floyd's Brother Urges Peace," Associated Press, June 1, 2020, https://www.oregonlive.com/nation/2020/06/trump-declares-himself-president-of-law-and-orderthreatens-use-of-military-on-protesters.html. For criticism, see, Thomas Gibbons-Neff et al., "Former Commanders Fault Trump's Use of Troops Against Protesters," New York Times, June 2, 2020, updated July 9, 2020, https://www.nytimes.com/2020/06/02/us/politics/military-national-guard-trump-protests.html; and Steven Nelson, "Defense Secretary Mark Esper Opposes Trump on Use of Military in Riots," New York Post, June 3, 2020, https://nypost.com/2020/06/03/defense-secretary-opposes-trump-on-use-of-military-inriots/.

${ }^{28}$ The Posse Comitatus Act is a reflection of the often close relationship between race and regulation of the use of force in much of American history. Its impetus was the resentment of the South to the use of federal troops to enforce Reconstruction and protect newly freed blacks from violence. Federal troops were withdrawn from the South in 1877 in exchange for Southern support that enabled Rutherford B. Hayes to become president as a result of the election of 1876. Southern Democrats then gained passage of the act in 1878. William C. Banks and Stephen Dycus, Soldiers on the Home Front: The Domestic Role of the American Military (Cambridge, MA: Harvard University Press, 2016), 72. For Mattis" quote, see, "Former Defense Secretary Mattis' Statement on Trump and Protests."

${ }^{29}$ David Davenport and Gordon Lloyd, "The Rise of the War Metaphor in Public Policy," Hoover Institution, May 6, 2019, https://www.hoover.org/research/rise-war-metaphor-public-policy.
} 
toward law enforcement..$^{30}$ President Richard Nixon stated that drug use was "public enemy number one" and declared a war on drugs in 1973. President Ronald Reagan elevated the prominence of this campaign and devoted substantial resources to waging it. Between 1982 and 2007, the number of arrests for drug possession tripled, from approximately 500,000 to 1.5 million per year. ${ }^{31}$ Several scholars have described how this campaign resulted in substantial increases in incarceration, especially of African American males. ${ }^{32}$

James Forman Jr. has documented how the support for the war on drugs among influential leaders in the African American community gave it substantial momentum. ${ }^{33}$ These leaders knew that expanded enforcement of drug laws would affect a disproportionate number of persons of color, but they were willing to accept this because of their concern that drugs were destroying minority communities. As Forman emphasizes, African American leaders believed that increasing drug prosecutions should have been accompanied by devoting substantial resources to these communities to strengthen education and social services, and to enhance economic opportunities, something that unfortunately never occurred.

As warriors in a war on drugs, police must act aggressively in ways that go beyond normal police practice. Eliav Lieblich and Adam Shinar observe, "War ... is the quintessential military concept, packing almost mythical powers as the ultimate state of exception." ${ }^{4}$ In particular, it authorizes a more expansive use of force and a greater restriction of liberty than in peacetime because of the gravity of the threats that the government has to combat. Lieblich and Shinar suggest, "In terms of political discourse, the war metaphor serve[s] to elevate certain categories of crime to existential national security threats, certain types of criminals to enemies, and thus certain types of situations to exceptional ones."35

\footnotetext{
${ }^{30}$ Susan P. Stuart, "War as Metaphor and the Rule of Law in Crisis: The Lessons We Should Have Learned from the War on Drugs," Southern Illinois University Law Journal 36, no. 1 (Fall 2011): 5, https://law.siu.edu/academics/law-journal/issues/fall-2011.html. On metaphors for policing and the public sentiments they elicit, see, Paul H. Thibodeau, Latoya Crow, and Stephen J. Flusberg, "The Metaphor Police: A Case Study of the Role of Metaphor in Explanation," Psychonomic Bulletin and Review 24 (2017): 1375-86, https://doi.org/10.3758/s13423-016-1192-5.

${ }^{31}$ Hannah L.F. Cooper, "War on Drugs Policing, and Police Brutality," Substance Use and Misuse 50, no. 8-9 (2015): 1188-1194, https://dx.doi.org/10.3109\%2F10826084.2015.1007669.

32 See, Alexander, New Jim Crow; Forman, Locking Up; and Doris Marie Provine, "Race and Inequality in the War on Drugs," Annual Review of Law and Social Science, no. 7 (December 2011): 41-60,

https://doi.org/10.1146/annurev-lawsocsci-102510-105445. See also, Marc Mauer, Race to Incarcerate (New York: The New Press, 2006).

${ }^{33}$ Forman, Locking Up, 17-46.

34 Eliav Lieblich and Adam Shinar, "The Case Against Police Militarization," Michigan Journal of Race and Law 23, no. 1-2 (2018): 113, https://repository.law.umich.edu/mirl/vol23/iss1/4. See also, Stuart, "War as Metaphor"; and Erik Luna, "Drug War and Peace," UC Davis Law Review 50, no. 2 (2016): 813, https://lawreview.law.ucdavis.edu/issues/50/2/Topic/50-2 Luna.pdf.

${ }^{35}$ Lieblich and Shinar, "Case Against Police Militarization," 114.
} 
Police wage war through a variety of operations and tactics designed to take the fight to the enemy. These include undercover sting operations, pretextual stops for minor legal violations, various surveillance techniques, and surprise raids designed to obtain evidence for arrests. ${ }^{36}$ As Peter Kraska and Victor Kappeler have described, "Rather than reactively responding to traditional crimes such as robbery, the police can go into the population and proactively produce cases against an almost limitless number of drug users and low-level dealers." 37

While these aggressive tactics may seem like the opposite of community policing, the two are presented as complementary in programs such as the Department of Justice "weed and seed" program, which gave assistance to law enforcement agencies from 1991 to 2009. As the Justice Department described it, the program was based on "a two-pronged approach to crime control and prevention: Law enforcement agencies and prosecutors cooperate in 'weeding out' criminals from the designated area. 'Seeding' brings prevention, intervention, treatment, and neighborhood revitalization services to the area." 38 The idea is that aggressive police work establishes order in the community, which in turn provides a foundation for efforts by residents to build social networks and physical infrastructure. ${ }^{39}$

Police leaders have elaborated on the rationale for this approach. One police chief of a department that sees itself as engaged in community policing, for instance, describes it this way:

The only people that are going to be able to deal with these problems (drugs, guns, gangs, and community disorder) are highly trained tactical teams with the proper equipment to go into a neighborhood and clear the neighborhood and hold it; allowing community policing and problem-oriented policing officers to come in and start turning the neighborhood around. ${ }^{40}$

Similarly, a Special Weapons and Tactics (SWAT) team commander explains how his unit's operations support community policing:

We conduct a lot of saturation patrol. We do "terry [reasonable suspicion] stops" and aggressive field interviews. These tactics are successful as long as the pressure stays on relentlessly. The key to our success is that we're an

\footnotetext{
${ }^{36}$ Mona Lynch, "Theorizing the Role of the 'War on Drugs' in US Punishment," Theoretical Criminology 16, no. 2 (2012): 175, 177, https://doi.org/10.1177\%2F1362480612441700.

37 Peter B. Kraska and Victor E. Kappeler, "Militarizing American Police: The Rise and Normalization of Paramilitary Units," Social Problems 44, no. 1 (February 1997): 7, https://doi.org/10.2307/3096870.

38 The Weed and Seed Strategy, U.S. Department of Justice, November 2004, 1, https://www.ncirs.gov/pdffiles1/207498.pdf.

${ }^{39}$ Kraska, "Militarization and Policing," 509-10.

${ }^{40}$ Kraska and Kappeler, "Militarizing American Police," 13.
} 
elite crime fighting team that's not bogged down in the regular bureaucracy. We focus on "quality of life" issues like illegal parking, loud music, bums, troubles. We have the freedom to stay in a hot area and clean it up particularly gangs. Our tactical team works nicely with our department's emphasis on community policing. ${ }^{41}$

As this quote illustrates, the war metaphor can be extended beyond drugs to include enemies who threaten order in a variety of ways. Kraska suggests that police in these operations "are integrating a military-model approach - occupy, suppress through force, and restore the affected territory." 42 The emphasis is on "taking back the neighborhood, creating a climate of order, and aggressively enforcing minor law and order infractions; all in an effort to cultivate healthier communities." 43

Those who are familiar with military operations will recognize the similarity of this approach to the "clear, hold, and build" counter-insurgency strategy employed by the U.S. military in Iraq and Afghanistan in the late 2000s. The 2014 U.S. Army counter-insurgency manual says that this begins with a preliminary phase in which "the population needs to understand that there will be an increase in security and initially local leaders should be contacted." 44 Thereafter, "the clear phase is an effort to remove the open insurgent presence in an area." 45 Next comes the hold phase, which "is defined by providing security for the population in an area [in which] open insurgent presence cannot return." 46 Finally, "the build phase entails efforts to increase security and governmental capacity so that government and local forces can control the area and prevent the return of insurgents." 47 Once this occurs, control is transferred to local leaders in a given area.

Police used this approach in an operation conducted in Pittsburgh in August 2007. In response to six shootings in three incidents in the Homewood neighborhood, police conducted a sweep of 27 abandoned homes, looking for drugs and guns. The operation included a Ballistic Engineered Armored Response vehicle with bulletproof plating, a state police helicopter, 20 police cruisers, and a SWAT team. ${ }^{48}$ The 20 -ton armor-plated vehicle holds 12-14 police officers in full tactical gear, has four "gun ports" on each side that can accommodate sniper rifles, and has a rooftop hatch that opens into a rotating turret. It has "extra ramming power" to push aside cars, walls, and doors. No one was arrested during the two-day sweep.

\footnotetext{
${ }^{41}$ Kraska and Kappeler, "Militarizing American Police," 7.

${ }^{42}$ Kraska, "Militarization and Police," 509.

${ }^{43}$ Kraska, "Militarization and Police," 510.

${ }^{44}$ FM 3-24 MCWP 3-33.5: Insurgencies and Countering Insurgency, U.S. Department of the Army, May 2014, https://fas.org/irp/doddir/army/fm3-24.pdf.

${ }^{45}$ FM 3-24, 9-3.

46 Ibid.

47 Ibid.

${ }^{48}$ Charlie Deitch, "Military Police," Pittsburgh City Paper, March 22, 2007.

https://www.pghcitypaper.com/pittsburgh/military-police/Content?oid=1335005
} 
Four months later, police conducted another eight-hour sweep in four neighborhoods, which police called a "saturation patrol."49 It included a helicopter and dozens of officers from city, state, and federal law enforcement agencies. According to the police, such patrols do not target specific individuals, but neighborhoods where police expect to find criminal activity. ${ }^{50}$ They begin with an advance team of plainclothes officers who set up on corners to identify anyone who may be dealing drugs or carrying weapons. ${ }^{51}$ Once they do, uniformed police in bulletproof vests make arrests and conduct searches. All the neighborhoods targeted by these two sweeps were predominantly African American.

Operations such as these involve displays of equipment meant to serve as a deterrent to any unlawful behavior, similar to a show of force by the military. ${ }^{52}$ No actual use of force may ensue, but the operation communicates the threat that it could be used. The police are presenting that they are engaged in a struggle with an enemy in which it may be necessary to use overwhelming force.

Police involvement in what has been called a war on terror also reinforces a military orientation. As one publication directed to the law enforcement community argued, "Local officers are ... [m]ore likely than federal terrorism agents to encounter suspicious activity that could be related to terrorism." 53 Police, therefore, can "act as extra eyes and ears for the various federal agencies that investigate terrorism cases" if they operate with a "heightened cognizance of the terrorist threat." 54 This focus on terrorist threats may expand the universe of persons considered objects of suspicion beyond African Americans to those of Arab or South Asian descent. ${ }^{55}$

In addition, since the Sept. 11, 2001 attacks, police have sought to increase their ability to deal with terrorism in the United States, adopting military weapons, tactics, and training methods and seeking to inculcate what Arthur Rizer calls a "soldier's mentality."56 Substantial Department of Homeland Security funds have been provided to local police departments since 2002 for counter-terrorism in order to enable surveillance of potential security threats. ${ }^{57}$ The result is that, "by bringing international counter-terrorism techniques to bear on domestic citizens, police departments have abandoned a focus on deescalation and crowd control in favor of an approach that treats political dissent as a

\footnotetext{
${ }^{49}$ Deitch, "Military Police."

50 Ibid.

51 Ibid.

52 DOD Dictionary of Military and Associated Terms, U.S. Department of Defense, June 2020, 196, https://www.jcs.mil/Portals/36/Documents/Doctrine/pubs/dictionary.pdf?ver=2020-06-18-073638-727.

${ }^{53}$ Jeremy Nikolow and Anthony Galante, "The Role of Local Police in the War Against Terrorism," In Public Safety, Nov. 16, 2015, https://inpublicsafety.com/2015/11/the-role-of-local-police-in-the-war-againstterrorism/. 
coordinated threat." 58 As with the war on drugs, the war on terror proclaims a state of exception in which police operations need not stringently follow normal procedures. ${ }^{59}$

Emphasis on the wars on drugs and terror have resulted in greater militarization of training in many police forces. Rosa Brooks' research on American policing leads her to conclude that "[t]he majority of law-enforcement academies in the United States are loosely modeled on military boot camps."60 Over the past two decades, the speaker who has probably helped train more police departments than anyone else is Dave Grossman, a former West Point professor whose books deal with the psychological experience of killing and its aftermath. ${ }^{61}$ One article in 2017 estimated that he had spoken to more than 100 police departments across the country in the previous two years. ${ }^{62}$

Grossman refers to his area of expertise as "killology," and his work provides insights into the complex psychological and emotional consequences of taking life. "Our goal is never to kill," he says to police officers. "Our goal is to save lives." 63 At the same time, Grossman emphasizes to them, "We are at war. And our cops are the front-line troops in that war. You are the Delta force. You are the Green Berets. It's your job to put a piece of steel in your fist and kill those sons of bitches when they come to kill our kids." ${ }^{64} \mathrm{He}$ tells police that the level of urban violence today is unprecedented. He also tells them that "the number of cops murdered in the line of duty has skyrocketed. The systematic murder, ambush, and execution of cops has become the norm." 65 His goal is to make police officers more comfortable with the prospect of killing and to handle its psychological consequences. This message explicitly equates the police with the military and emphasizes the need for them to receive training comparable to that provided to military forces. As one person who took his class comments, "Combat has clear military connotations, and Grossman's frequent use of the term undergirds the course's martial framing." 66

In addition to an emphasis on the potential need to use lethal force, militarized police training sends subtler messages. As Brooks puts it,

\footnotetext{
${ }^{58}$ Bittle, "The NYPD Sees Coordination in Protests."

${ }^{59}$ Andrea J. Ritchie and Joey L. Mogul, "In the Shadows of the War on Terror: Persistent Police Brutality and Abuse of People of Color in the United States," DePaul Journal for Social Justice 1, no. 2 (Spring 2016): 175250, https://via.library.depaul.edu/jsi/vol1/iss2/3/; and Rens Van Munster, "The War on Terrorism: When the Exception Becomes the Rule," International Journal for the Semiotics of Law 17 (June 2004): 141, https://doi.org/10.1023/B:SELA.0000033618.13410.02.

${ }^{60}$ Rosa Brooks, "Stop Training Police Like They're Joining the Military," The Atlantic, June 10, 2020, https://www.theatlantic.com/ideas/archive/2020/06/police-academies-paramilitary/612859/.

${ }^{61}$ Dave Grossman, On Killing: The Psychological Cost of Learning to Kill in War and Society (New York: Little Brown, 2009); and Dave Grossman and Loren W. Christensen, On Combat: The Psychology and Physiology of Deadly Conflict in War and Peace (Millstadt, IL: Warrior Science Publications, 2008).

${ }^{62}$ Josh Eels, "Lt. Col. Dave Grossman, the 'Killologist' Training America's Cops," Men's Journal, Feb. 8, 2017, https://www.mensjournal.com/features/lt-dave-grossman-the-self-described-killologist-training-americascops-w463304/.

63 Eels, "Lt. Col. Dave Grossman."

64 Ibid.

65 Ibid.

${ }^{66}$ Justin Peters, “I Learned to Think Like a 'Warrior Cop,"' Slate, Aug. 28, 2020, https://slate.com/news-andpolitics/2020/08/warrior-cop-class-dave-grossman-killology.html.
} 
When police recruits are belittled by their instructors and ordered to refrain from responses other than "Yes, Sir!," they may learn stoicism - but they may also learn that mocking and bellowing orders at those with less power are acceptable actions. When recruits are ordered to do push-ups to the point of exhaustion because their boots weren't properly polished, they may learn the value of attention to detail - but they may also conclude that the infliction of pain is an appropriate response to even the most trivial infractions. ${ }^{67}$

Using a warfare metaphor in policing - whether in the war on drugs or the war on terror - is a crucial element of cultural militarization, one that can have a significant effect on how police officers regard their work and those whom they encounter while on duty. The next section describes how a variety of policing practices that do not involve the use of lethal force can nonetheless reflect a military orientation.

\section{Aggressive Preventive Policing}

Some of the operations I have described rely explicitly on the metaphor of war. But they also reflect a general movement over the last 25 years toward what I call "aggressive preventive policing." Tom Tyler, Jonathan Jackson, and Avital Mentovich describe this shift in policing practices: "The police have moved from a focus on acting against crime that is in the process of occurring or on solving already committed crimes to a proactive strategy of preventive measures aimed at deterring future crimes." 68 In many cases, these involve stops of individuals based on suspicion, rather than evidence, that they are engaged in illegal conduct.

Preventive policing in itself is not necessarily an indication of militarization. Research has identified various ways to attempt to prevent crime by combining professional expertise with community involvement. In particular, approaches that foster the perceived legitimacy of the police can increase community members' willingness to abide by the law, to report crimes, and to cooperate with the police in investigations. ${ }^{69}$ These can lead to long-term reductions in crime without the costs associated with aggressive preventive policing that I describe below.

\footnotetext{
${ }^{67}$ Brooks, "Stop Training the Police."

${ }^{68}$ Tom R. Tyler, Jonathan Jackson, and Avital Mentovich, "The Consequences of Being an Object of Suspicion: Potential Pitfalls of Proactive Police Contact," Journal of Empirical Legal Studies 12, no. 4 (2014): 602-36, https://doi.org/10.1111/jels.12086.

${ }^{69}$ See, for example, Matthew Desmond, Andrew V. Papachristos, and David S. Kirk, "Police Violence and Citizen Crime Reporting in the Black Community," American Sociological Review 81, no. 5 (October 2016): 857, https://doi.org/10.1177\%2F0003122416663494; Tyler, Jackson, and Mentovich, "Consequences of Being," 603, 629, 631; Charlotte Gill et al., "Community-Oriented Policing to Reduce Crime, Disorder and Fear and Increase Satisfaction and Legitimacy Among Citizens: A Systematic Review," Journal of Experimental Criminology, no. 10 (December 2014): 399, https://doi.org/10.1007/s11292-014-9210-y; Andrew V. Papachristos, Tracy L. Meares, and Jeffrey Fagan, "Why Do Criminals Obey the Law? The Influence of Legitimacy and Social Networks on Active Gun Offenders," Journal of Criminology and Criminal Law, 102, no. 2 (Spring 2012): 397, https://scholarlycommons.law.northwestern.edu/cgi/viewcontent.cgi?article=7426\&context=jclc.
} 
This section discusses the origins of this form of preventive policing and its rationale. It then examines evidence indicating that enforcing marijuana laws, the New York stop-and-frisk program that has been ruled unlawful, and routine traffic stops all reflect implicit treatment of racial and ethnic minorities, especially African American men, as potential threats. Next, it discusses how this orientation is reinforced by police officer perceptions of being in danger, and concludes with a review of the research on the effects of aggressive preventive policing on criminal activity.

\section{The History of Aggressive Preventive Policing}

Police work has always been preventive to some extent. Police patrols on foot or in police cars are traditional efforts to prevent crime rather than simply reacting to it. In contrast, aggressive preventive policing involves three things: The first is the practice of increasing the number of stops and arrests for minor crimes in the belief that this will take people who are likely to commit more serious crimes off the streets. The second is an expansive interpretation of what constitutes "reasonable suspicion" of criminal activity as a basis for stopping, questioning, and frisking individuals. The third is prominent displays of force, including using military equipment, in certain communities with the aim of deterring crime.

One result has been more frequent police initiation of contact with individuals. ${ }^{70}$ Another has been a change in the nature of the contact between the police and the public, "as the police now more frequently approach members of the public with an attitude of suspicion and distrust as they search for signs of criminal character and likely future criminal behavior."71

One impetus for this shift in policing is the well-known "broken windows" approach that began in the early 1980s during a period of high crime rates in the United States. ${ }^{72}$ This method is based on the belief that failure to address minor crimes that contribute to a community's sense of fear - such as public intoxication, rowdy people on the street, and groups or individuals verbally accosting passers-by - will lead to more serious crime because of the perception that police are not interested in maintaining public order. ${ }^{73}$ Responding to these minor crimes is seen as a way for police to deter more serious ones.

Tyler, Jackson, and Mentovich suggest that the original "broken windows" approach reflected collaboration between police and the community. Police focused on

\footnotetext{
70 Tyler, Jackson, and Mentovich, “Consequences of Being,” 604.

71 Tyler, Jackson, and Mentovich, “Consequences of Being," 604.

72 The inspiration for this was George L. Kelling and James Q. Wilson, "Broken Windows: The Police and Neighborhood Safety," The Atlantic, March 1982, 29-38, https://www.theatlantic.com/magazine/archive/1982/03/broken-windows/304465/.

${ }^{73}$ Kelling and Wilson, "Broken Windows." See also, Franklin E. Zimring, The City that Became Safe: New York's Lessons for Urban Crime and Its Control (New York: Oxford University Press, 2012).
} 
those disorderly individuals whose behavior was viewed by the community as outside the rules of everyday social order (i.e., outside the communities' normative consensus about appropriate behavior). In other words, in the original model, the norms being enforced reflected the norms of the general community. ${ }^{74}$

Police also used a variety of methods to deter such aberrant behavior. As George Kelling, one of the originators of the approach, has said, "Neighborhood rules were to be enforced for the most part through non-arrest approaches ... so that arrest would only be resorted to when other approaches failed."75

The shift to "zero-tolerance" policing, however, was based on a belief that stopping people for minor crimes would reveal that some of them were engaged in more serious crimes or had outstanding warrants. ${ }^{76}$ A RAND report describes this approach:

A zero tolerance strategy consists of stopping, questioning, and frisking pedestrians or drivers considered to be acting suspiciously and then arresting them for offenses whenever possible, typically for such low-level offenses as possessing marijuana. A defining difference between zero tolerance interventions and other strategies is that zero tolerance strategies are not discerning; the focus is on making stops and arrests to crack down on all types of disorder, generically defined..$^{77}$

As a result, in New York, the reason for apprehending persons engaged in low-level offenses shifted from promoting a climate of social order to catching more serious criminals. ${ }^{78}$ The reasoning became that "[s]topping and frisking numerous ordinary citizens ... would make the people carrying illegal guns fear that their weapons would be discovered during an arrest for a more minor offense."79 Stopping more people thus increased the odds that at least some of them were persons engaged in serious crimes.

Police therefore began "to draw a larger segment of the community into the criminal justice system for minor lifestyle crimes, with many of those people being more integral members of the community, not outsiders or 'marginal' people." 80 Despite its name, the zero-tolerance approach could never be strictly implemented as a practical matter. There are simply not enough police to stop everyone engaged in minor legal violations. Police

\footnotetext{
${ }^{74}$ Tyler, Jackson, and Mentovich, "Consequences of Being," 607.

${ }^{75}$ Quoted in Jeffrey Rosen, "Excessive Force, New Republic, April 9, 2000, https://newrepublic.com/article/74124/excessive-force.

${ }^{76}$ As Jeffrey Rosen observes in his assessment of New York City, when the "broken windows" approach shifted to "zero tolerance" is difficult to identify precisely, but he suggests that it occurred in the mid- to late1990s in New York City. Rosen, "Excessive Force."

77 "Zero Tolerance and Aggressive Policing (And Why to Avoid It)," RAND Corporation, accessed July 7, 2020, https://www.rand.org/pubs/tools/TL261/better-policing-toolkit/all-strategies/zero-tolerance.html.

78 Rosen, "Excessive Force."

${ }^{79}$ Rosen, "Excessive Force."

80 Tyler, Jackson, and Mentovich, "Consequences of Being," 607-08. See also, Andrea McArdle and Tanya Erzen, eds., Zero Tolerance: Quality of Life and the New Police Brutality in New York City (New York: New York University Press, 2001).
} 
inevitably will have to exercise discretion about whom to stop. As several scholars who have studied police operations have documented, the policy of zero tolerance combined with reliance on implicit racial stereotypes in implementing that policy resulted in a substantial increase in arrests and incarceration of racial and ethnic minorities. ${ }^{81}$ For instance, 85 percent of marijuana arrests in New York City in 2016 were of blacks and Latinos, and 15 percent were of non-Latino whites. ${ }^{82}$ National data indicate, however, that the same percentage of people in each of these groups use marijuana. Moreover, among people ages 18 to 25, a higher percentage of non-Latino whites use marijuana than blacks and Latinos. ${ }^{83}$

Reliance on preventive logic continued to expand in the late 1990s and into the 2000s, with police stopping individuals not overtly engaged in any crime but whom police suspected might be illegally in possession of contraband or guns. New York City's stop-andfrisk program, which was struck down in 2014, was a prominent example of this approach. ${ }^{84}$ It resulted in more than 4.4 million stops by police between 2004 and 2012, most of which involved members of minority groups. ${ }^{85}$ The two most common reasons for a stop were that the individual was in a "high-crime area" (55 percent) or had exhibited "furtive movements" (42 percent), both of which gave the police expansive discretion. ${ }^{86}$

While the New York City stop-and-frisk program has ended, aggressive preventive policing is likely to continue in other forms. A study of 100 million traffic stops between 2011 and 2018 found, when controlling for relevant variables, that decisions about whom to stop, and whom to search during a stop, have a disproportionate impact on "black and Hispanic drivers." 87 Similarly, in a study conducted by Charles Epp, Steven MaynardMoody, and Donald Haider-Markel on traffic stops, African Americans were pulled over much more often than whites "for more arbitrary, and often unexplained, reasons." 88 Only 8 percent of white drivers were given no reason for the stop, while almost 18 percent of African Americans were given no reason. ${ }^{89}$ When officers did give a reason, about twice as many black drivers as white drivers were stopped for highly discretionary reasons such as driving too slowly, having a burned-out license plate light, or simply to check whether the

\footnotetext{
${ }^{81}$ See, Alexander, New Jim Crow; and Forman, Locking Up. See also, Elizabeth Hinton, From the War on Poverty to the War on Crime: The Making of Mass Incarceration in America (Cambridge, MA: Harvard University Press, 2016).

82 Harry Levine, “Unjust and Unconstitutional: 60,000 Jim Crow Marijuana Arrests in Mayor deBlasio’s New York,” Drug Policy Alliance \& Marijuana Arrest Research Project, July 2017, 7,

https://drugpolicy.org/sites/default/files/Marijuana-Arrests-NYC--Unjust-Unconstitutional--July2017 2.pdf.

83 Levine, Unjust and Unconstitutional 7.

${ }^{84}$ David Floyd v. New York, 959 F. Supp. 2d 540 (S.D.N.Y. 2013).

${ }^{85}$ Annual Report 2013, New York Civil Liberties Union, 2014

https://www.nyclu.org/sites/default/files/publications/Annual-Report-2013-Web.pdf; See also J. Fagan,

"Report to the Court, October 15, 2010," in David Floyd et al. v. The City of New York (S.D.N.Y. 2008);

“Testimony, April 4, 2010," in David Floyd et al. v. The City of New York, (S.D.N.Y. 2013).

86 David Floyd v. The City of New York, 959 F.Supp.2d, 540, 559 (S.D.N.Y. 2013).

${ }^{87}$ Emma Pierson et al., "A Large-Scale Analysis of Racial Disparities in Police Stops Across the United States," Nature Human Behavior, no. 4 (2020): 736-45, https://www.nature.com/articles/s41562-020-0858-1.

88 Epp, Maynard-Moody, and Haider-Markel, Pulled Over, 72

89 Ibid.
} 
driver had an outstanding arrest warrant, which is not legal authority for a stop. ${ }^{90}$ Whites and blacks are equally likely, however, to be stopped for serious traffic violations such as speeding. ${ }^{91}$ Thus, as the authors conclude, the wide racial disparity in the likelihood of being stopped is confined to discretionary stops for minor traffic violations. ${ }^{92}$ "Police have told us," the authors state, "they use drivers' minor violations of the law when they want to investigate the driver on suspicion of criminal activity." 93 Since race is such a strong influence in such stops, it is not hard to imagine why many African Americans believe that "[i]nstead of respecting those in the community, the police view them as potential criminals and wrongdoers." 94

Some may claim that police stop racial and ethnic minorities more often because the percentage of crimes they commit is higher, in some cases substantially so, than the percentage of the population that is made up by members of these groups. ${ }^{95}$ The problem with this claim is that the vast majority of racial and ethnic minorities commit no crimes. Police are justified in stopping and questioning them only on the basis of individual evidence of suspected wrongdoing. Racial or ethnic minority status does not constitute such evidence. To treat it as such is to impose a form of collective responsibility for the wrongdoing of others on law-abiding individuals who share a physical characteristic with those criminals.

The experience with aggressive preventive policing thus indicates that even when it does not rely on overt military tactics and equipment, it can subtly shift officers' orientation so that it resembles the mindset of a warrior in a hostile environment. Military forces in a theater of conflict see themselves as fighting enemies who are not part of their community. They regard others as potential hostile actors, rather than persons who are presumptively benign. When enemies are embedded in the community and do not wear uniforms, this attitude of suspicion can extend to a large portion of people in the community. As in asymmetric military conflict, enemies may receive aid from the local population in various forms. This widens the universe of suspects to include those who may be assisting the enemy. Some police thus may regard patrolling a neighborhood in America as akin to patrolling one in a military conflict abroad.

While the military does not officially use the term, soldiers on the front lines have sometimes used the category of "military-age males" to refer to potentially hostile persons. ${ }^{96}$ This can shape how ambiguous behavior is interpreted in ways that result in loss of innocent life. ${ }^{97}$ Similarly, police officers may view young men of color as presumed

\footnotetext{
${ }^{90}$ Epp, Maynard-Moody, and Haider-Markel, Pulled Over, 71-72.

${ }^{91}$ Epp, Maynard-Moody, and Haider-Markel, Pulled Over, 72.

92 Ibid.

93 Ibid.

94 Tyler, Jackson, and Mentovich, "Consequences of Being," 617.

95 "Crime in the United States 2018, Table 43: Arrests by Race and Ethnicity," FBI, Criminal Justice Information Services Division, https://ucr.fbi.gov/crime-in-the-u.s/2018/crime-in-the-u.s.2018/tables/table-43.

${ }^{96}$ Kevin Mullaney and Mitt Regan, "One Minute in Haditha: Ethics and Non-Conscious Decision Making," Journal of Military Ethics 18, no. 2 (2019): 75-95, https://doi.org/10.1080/15027570.2019.1643593. ${ }^{97}$ Mullaney, "One Minute."
} 
suspects rather than as fellow citizens, which could lead an officer to construe ambiguous behavior as hostile, something that could prompt an escalation in the use of force.

\section{Racial and Ethnic Minorities and the "Danger Imperative"}

Police perception of being in constant danger may increase the likelihood that the behavior of young men of color will be construed as threatening. Michael Sierra-Arévalo suggests that police officers' understanding of their work is powerfully shaped by what he calls "the danger imperative,"98 a cultural frame that emphasizes the constant danger of lethal violence against police officers. According to Sierra-Arévalo, information that the police receive is

interpreted through the frame of the danger imperative, [with] emphasis placed on person-to-person violence in the line of duty. This "social amplification" dramatically highlights statistically rare events, such as in the re-telling of departmental "war stories" that provide officers with vivid evidence of just how dangerous their work is. ${ }^{99}$

This perspective leads police to be ever-alert to the possibility of violence in their encounters with individuals, which in turn creates the risk of escalation. Given the prevalence of the danger imperative among the police, increasing the number of interactions with citizens through aggressive preventive policing increases the number of occasions on which police may regard individuals not only as suspects but as potential threats. This form of policing thus can produce more encounters in which police communicate that people in a community cannot be trusted.

Furthermore, an officer's reliance on implicit racial assumptions may intensify a sense of danger, so that a large percentage of police interactions with members of minority groups become adversarial. For instance, while he stresses the limitations of his study, recent experimental research by Scott Phillips indicates that whether a person is black, along with the time of day and the person's manner of clothing, is statistically significant in contributing to the formation of suspicion by police officers. ${ }^{100}$ The interaction between the danger imperative and the perception that minority group members are especially likely to pose a threat suggests that, in addition to its other impacts, aggressive preventive policing may increase the risk that police will use lethal force against racial and ethnic minorities.

\section{Effects of Aggressive Preventive Policing on Crime}

\footnotetext{
98 Michael Sierra-Arévalo, “American Policing and the Danger Imperative,” unpublished manuscript, 2020, https://papers.ssrn.com/sol3/papers.cfm?abstract id=2864104. See also, Michael Sierra-Arévalo, "The Commemoration of Death, Organizational Memory, and Police Culture," Criminology 57, no. 4 (November 2019): 632, https://doi.org/10.1111/1745-9125.12224.

99 Sierra-Arévalo, "American Policing," 14.

100 Scott W. Phillips, "The Formation of Suspicion: A Vignette Study," International Journal of Police Science and Management 22, no. 3 (2020): 274-84, 280, https://doi.org/10.1177\%2F1461355720929038.
} 
Evidence suggests that using more frequent stops to cast a wide net in the hope of catching serious criminals is ineffective in preventing crime. The Committee to Review Research on Police Policy and Practices, for instance, concluded that, with respect to "undifferentiated intensive enforcement activities, studies fail to show consistent or meaningful crime or disorder prevention benefits." 101 In addition, analysis of the stop-andfrisk program in New York City indicates that, between 2003 and 2009, only 0.15 percent of stops yielded guns, 1.09 percent produced weapons other than guns, and 1.7 percent yielded contraband. 102

Franklin Zimring has conducted an especially careful study of the extent to which different police policies contributed to New York City's greater decline in crime compared with the rest of America during a time of substantial decline in crime across the country, beginning in the early 1990s. One such policy he examines is "the very aggressive use of stops by the police, stop and frisk procedures, and arrests of suspicious persons for minor crimes to remove them from being an immediate threat and to identify persons with outstanding warrants." 103 He concludes that there are "no plausible indications" that this approach helped prevent crime. ${ }^{104}$ Beyond New York City, Zimring's 2008 analysis of the national decline in crime cautioned that the decline "was a surprise when it began and is a mystery to this day. ... [T] here is little consensus among experts about what changes in circumstances produced the crime decline."105

Even if aggressive preventive policing has contributed to a decline in crime, Zimring notes that "aggressiveness in policing is a costly strategy because it imposes real disadvantages on exactly the minority poor who can least afford additional handicaps."106 We need to investigate what these costs are. Jeffrey Fagan and his colleagues have noted, with respect to aggressive street stops, the harm of "stigma and internalized psychological costs" for the 95 percent of people who are innocent in these stops. ${ }^{107}$ Epp, MaynardMoody, and Haider-Markel's study of traffic stops observes that "every stop justified by a minor violation, every inquisitive question, every light shined in a passenger compartment, every request for consent to search, every search, and every handcuffing of a person only to

\footnotetext{
101 Wesley Skogan and Kathleen Frydl, eds., Fairness and Effectiveness in Policing: The Evidence (Washington, DC: The National Academies Press, 2004), 250, https://www.nap.edu/initiative/committee-to-reviewresearch-on-police-policy-and-practices.

102 Delores Jones-Brown, Jaspreet Gill, and Jennifer Trone, Stop, Question and Frisk Policing Practices in New York

City: A Primer, Center for Race, Crime and Justice, John Jay College of Criminal Justice, March 2010, http://www.roosevelthouse.hunter.cuny.edu/devdev/wpcontent/uploads/2013/11/PRIMER electronic version.pdf

103 Zimring, The City that Became Safe.

104 Zimring, The City that Became Safe.

105 Franklin E. Zimring, The Great American Crime Decline (New York: Oxford University Press), i.

106 Zimring, The City that Became Safe, 149.

${ }^{107}$ Jeffrey A. Fagan et al., "Street Stops and Broken Windows Revisited: The Demography and Logic of Proactive Policing in a Safe and Changing City," in Race, Ethnicity, and Policing: New and Essential Readings, ed. Stephen K. Rice and Michael D. White, (New York University Press, 2010), 309, 335.
} 
release them later causes harm."108 Similarly, the 2015 Department of Justice report on the Ferguson Police Department found that African American residents "described being belittled, disbelieved, and treated with little regard for their legal rights."109

A subtler cost is heightened police suspicion of and distance from the communities they serve, thus increasing officers' perception that individuals are threatening and that force is necessary to subdue them. As the Ferguson report suggested, this adversarial posture can undermine efforts to reduce crime because it can "increase distrust and significantly decrease the likelihood that individuals will seek police assistance even when they are victims of crime, or that they will cooperate with the police to solve or prevent other crimes." 110

In sum, the practice of aggressive preventive policing reflects cultural militarization because it relies on a view of minority groups as a segment of the population that is especially likely to pose threats from which police must protect society. It aims to prevent crime by focusing more intensive police attention on racial and ethnic minorities, based on the view that this is likely to identify wrongdoers who should be kept off the streets. This conceives of minority communities as adversaries whose members should be approached as suspects rather than fellow citizens. To the extent that police perceptions of personal danger are implicitly shaped by these assumptions, more frequent interaction between police and suspects also creates the risk of greater use of police violence. As the next section describes, the trend toward more heavily armed patrol officers may increase the risk that this violence will be lethal.

\section{Heavily Armed Regular Police}

Another aspect of cultural militarization is the belief that regular police officers need military-grade weapons to do their job. While the possession of such weapons represents a material dimension (something I will discuss in more detail in the next section), the conviction that police officers need them reflects a subtle cultural shift in the understanding of the nature of police work. This conviction rests on three questionable assumptions: that police and criminals are engaged in an arms race; that mass shootings are becoming more common; and, in the view of at least some in the law enforcement community, that a "war on cops" has arisen in recent years.

\section{A Domestic Arms Race}

The iconic event that sparked concern about an arms race was a 1997 shootout in North Hollywood, California, between two heavily armed bank robbers and the Los Angeles

\footnotetext{
${ }^{108}$ Epp, Maynard-Moody, and Haider-Markel, Pulled Over, 161.

${ }^{109}$ Investigation of the Ferguson Police Department, U.S. Department of Justice, Civil Rights Department, March 4, 2015, 79, https://www.justice.gov/sites/default/files/opa/pressreleases/attachments/2015/03/04/ferguson_police department report.pdf.

110 Investigation of the Ferguson Police Department, 81.
} 
police. ${ }^{111}$ The two criminals had three different types of semi-automatic rifles, which had been modified to enable fully automatic fire. They also wore mostly homemade, heavyplated body armor that protected them from handgun rounds and shotgun pellets fired by the police. The two men fired approximately 1,100 total rounds. According to one report, "During the gun battle, police officers were forced to run to a local gun store and take rifles to try to contend with the robbers' firepower and body armor."112

Following the shootout, many police departments across the country began issuing semi-automatic weapons to regular officers. A decade later, $C N N$ reported that there was a "war on the streets" in which the acquisition of greater firepower by criminals was leading police to say that they were in "an arms race."113 The article reported a police officer in Palm Beach County, Florida, saying, "[Criminals] don't have .38s anymore. They have AK47s. ...They have automatic weapons now."114 The Miami police chief reported that the department was in the process of providing an assault rifle to every officer based on concerns that AK-47s and assault weapons from former Soviet bloc countries were flooding into southern Florida. ${ }^{115}$

The Brady Center to Prevent Gun Violence argues that the 2004 expiration of the federal ban on assault weapons has intensified the arms race, and that "[p]olice officers need to be able to defend themselves and the rest of us, and they need the weapons to do so." 116 "This is a national problem," said the Miami police chief. "Police agencies all over the U.S. are going to bigger weapons." 117

Despite this perception of an arms race, the most current data from the FBI indicate that, of the 10,265 murders involving a firearm in the United States in 2018, handguns were used in 6,603 of them and rifles of any kind in only 297.118 Phillips, a criminal justice scholar, describes the belief that military-style assault weapons are commonly used in homicides as a "myth," noting that police rarely recover such weapons in their

\footnotetext{
${ }^{111}$ Fredrik Redhe, "North Hollywood Shootout," Crime Scene Database, last modified Dec. 7, 2015, http://crimescenedb.com/north-hollywood-shootout/.

112 Ali Watkins, John Ismay, and Thomas Gibbons-Neff, "Once Banned, Now Loved and Loathed: How the AR15 Became 'America's Rifle,'” New York Times, March 3, 2018, https://www.nytimes.com/2018/03/03/us/politics/ar-15-americas-rifle.html.

${ }^{113}$ Susan Candiotti, "Cops Find Themselves in Arms Race with Criminals, CNN, Nov. 5, 2007, https://www.cnn.com/2007/US/11/05/cops.guns/index.html.

114 Candiotti, "Cops Find Themselves."

115 Ibid.

116 Keith Ridler, "Police's Heavy-Duty Guns in Arms Race with Criminals," Associated Press, August 8, 2011, https://www.chron.com/news/nation-world/article/Police-s-heavy-duty-guns-in-arms-race-with1761813.php.

117 Ridler, "Police's Heavy-Duty Guns in Arms Race with Criminals."

118 "Crime in the United States 2018, Expanded Homicide Data Table 11," FBI, Criminal Justice Information Services Division, https://ucr.fbi.gov/crime-in-the-u.s/2018/crime-in-the-u.s.-2018/tables.
} 
operations. ${ }^{119}$ All this casts doubt on the claim that criminals are arming themselves with increasingly intensive weapons that require police to respond in kind.

\section{Mass Casualty Attacks}

The conviction that regular police need more firepower also stems from prominent mass casualty attacks that have taken place in recent years, which involved both "active shooters" who attempted to kill a large number of people in a confined space and "hybrid targeted violence" that aimed to harm an identified population using multiple weapons and tactics. $^{120}$

The shooting at Columbine High School in Colorado in 1999 "brought about a sea change in police tactics" in such situations. ${ }^{121}$ At Columbine, local police responded but did not enter the school to attempt to stop the shooters for more than half an hour because they were waiting for a SWAT team to arrive. At that time, SWAT teams were used for hostage incidents or cases in which suspects barricaded themselves. As a result of Columbine, however, where shooters focused on "quickly killing people at random," the law enforcement community concluded that a faster response was necessary. ${ }^{122}$

One police chief described how his department prepared for regular police officers serving as first responders in such incidents:

We have obtained a great deal of equipment for these types of incidents. We have purchased AR-15 style weapons for all sworn personnel. We have converted all our patrol vehicle shotguns to a type of breaching shotgun. We have purchased tactical vests with ceramic plates that are placed in every patrol vehicle. Supervisors have rams/sledge-hammers as well as other breaching tools in their vehicles. We are currently testing and evaluating additional breaching equipment to be placed in every patrol vehicle. ${ }^{123}$

Data indicate an increase in active-shooter events in recent years. Prior to 2014, the year the FBI began to issue annual reports on active-shooter incidents, a report on activeshooter incidents that took place between 2000 and 2013 indicated that 160 incidents

\footnotetext{
${ }^{119}$ Scott W. Phillips, "Myths, Militarism and the Police Patrol Rifle," Policing and Society 26, no. 2 (2016): 185-96, https://doi.org/10.1080/10439463.2014.922088. ${ }^{120}$ Active Shooter: How to Respond, U.S. Department of Homeland Security, October 2008, http://www.dhs.gov/xlibrary/assets/active shooter booklet.pdf; and Tracey L. Frazzano and G. Matthew Snyder, "Hybrid Targeted Violence: Challenging Conventional 'Active Shooter' Response Strategies," Homeland Security Affairs, no. 10 (February 2014), https://www.hsaj.org/articles/253.

${ }^{121}$ The Police Response to Active Shooter Incidents, Police Executive Research Forum, Critical Issues in Policing Series, March 2014, 1.

122 The Police Response to Active Shooter Incidents, 2.

123 The Police Response to Active Shooter Incidents, 27-28.
} 
causing 486 deaths occurred during this period. ${ }^{124}$ An average of 6.4 incidents per year occurred between 2000 and 2006, a number that jumped to an average of 16.4 between 2007 and 2013.125 Between 2014 and 2019, there were 145 active-shooter incidents resulting in 495 deaths. ${ }^{126}$ Annual casualties rose from 34 between 2000 and 2013 to 99 between 2014 and 2019. The number of incidents has ranged from 20 each year between 2014 and 2016 to 30 in 2017.127 The percentage increase in active-shooter incidents and casualties since 2000 is thus substantial. At the same time, however, they remain extremely rare events to which few regular officers will ever have to respond. Departments nonetheless believe that all officers should be prepared to do so.

A category of violent incidents that has recently emerged is hybrid targeted violence. These assaults "often use a combination of lethal conventional weapons (i.e., fire as a weapon, firearms, improvised explosive devices, chemical weapons, etc.) and a combination of well-planned tactics (i.e., ambush, breaching, barricading, maneuver, etc.)."128 Prominent examples of hybrid targeted violence include attacks by Islamic State members at the Brussels airport in 2016, in Paris in November 2015, and Nairobi in 2013; the bombing at the Boston Marathon in 2013; and attacks in Mumbai in 2008. While these are disturbing events, the total number of terrorist attacks worldwide decreased by 50 percent between 2014 and 2019, and the total number of deaths decreased by 54 percent. ${ }^{129}$ Between Sept. 11, 2001, and 2020, a total of 243 persons died in terrorist attacks in the United States, with the largest number due to attacks by domestic far rightwing groups. ${ }^{130}$ The FBI indicates that the dominant feature of the latter type of attack is a lone gunman. ${ }^{131}$ The average officer on patrol thus is highly unlikely to encounter hybrid targeted violence.

According to Phillips' study of the police's increasing possession of patrol rifles, such as the MP5, AR-15, or M16, police believe they need military-grade equipment to deal with

\footnotetext{
124 “Active Shooter Study: Quick Reference Guide,” U.S. Federal Bureau of Investigation, 2014, https://www.fbi.gov/file-repository/as-study-quick-reference-guide-updated1.pdf/view.

125 "Active Shooter Study," 1.

${ }^{126}$ See, "Active Shooter Incidents in the United States," U.S. Federal Bureau of Investigations, for 2014 and 2015, 2016, 2017, 2018, and 2019, available at, https://www.fbi.gov/about/partnerships/office-of-partnerengagement/active-shooter-resources.

127 See, "Active Shooter Incidents."

${ }^{128}$ Frazzano and Snyder, "Hybrid Targeted Violence," 2.

129 Global Terrorism Overview: Terrorism in 2019, National Consortium for the Study of Terrorism and Responses to Terrorism, July 2020, https://www.start.umd.edu/pubs/START GTD GlobalTerrorismOverview2019 July2020.pdf. 130 Peter Bergen et al., "Terrorism in America After 9/11: Part IV. What Is the Threat to the United States Today?" New America, https://www.newamerica.org/in-depth/terrorism-in-america/what-threat-unitedstates-today/, accessed Nov. 25, 2020.

${ }^{131}$ Miariam Valverde, "Terrorism in the United States: Key Facts, Patterns and Trends," Politifact, Dec. 5, 2019, https://www.politifact.com/article/2019/dec/05/terrorism-united-states-key-facts-patterns-andtre/.
} 
more active-shooter and terrorist incidents. ${ }^{132}$ These firearms were previously used almost exclusively by police paramilitary units, but are now being issued to officers on the street. While there is little empirical research on this phenomenon, the 2007 Law Enforcement Management and Administrative Statistics survey indicates that 68.4 percent of police departments "issue or authorize assault weapons as a secondary firearm system."133

And yet, the number of homicides involving police officers has fallen in the United States since 1973, and most homicides, including of police officers on duty, occur with handguns. ${ }^{134}$ Phillips maintains that it is unlikely that patrol rifles will increase shooting accuracy, referring to research that concludes that officers using semi-automatic sidearms are no more accurate than officers using revolvers. ${ }^{135}$ Despite these considerations, Phillips says that increasing use of the patrol rifle is consistent with police narratives of "crime prevention, crime-fighting, and danger," and the fear that police will be outgunned in the scenarios they are increasingly likely to encounter. For this reason, he says, police departments may feel the need to issue patrol rifles to officers regardless of empirical evidence casting doubt on the need for them. ${ }^{136}$

\section{The "War on Cops"}

Finally, some believe that police need to be more heavily armed to defend themselves in an ongoing "war on cops."137 Those who maintain that there is such a war argue that there is an increasing number of attacks on police officers motivated by hatred of police and the desire for revenge for police killings of citizens. ${ }^{138}$ As the president of the National Fraternal Order of Police wrote to President Barack Obama in 2016, "There is a very real and very deliberate campaign to terrorize our nation's law enforcement officers."139 Proponents of this view argue that the events surrounding the police killing of Michael Brown in Ferguson, Missouri, in 2014 have been the primary catalyst for this form of violence. 140

\footnotetext{
132 Phillips, "Myths, Militarism and the Police Patrol Rifle," 6.

133 Phillips, "Myths, Militarism and the Police Patrol Rifle," 6.

134 Phillips, "Myths, Militarism and the Police Patrol Rifle," 7.

135 Phillips, "Myths, Militarism and the Police Patrol Rifle," 7.

136 Phillips, "Myths, Militarism and the Police Patrol Rifle," 8.

137 Heather MacDonald, The War on Cops: How the New Attack on Law and Order Makes Everyone Less Safe (New York: Encounter Books, 2016); Larry Casey, “The War on Police Nationwide," Law Enforcement Today, May 20, 2018, https://www.lawenforcementtoday.com/war-police-nationwide/; "FBI Confirms the Deadly Costs of A 'War on Cops,'” New York Post, May 17, 2017, https://nypost.com/2017/05/07/fbi-confirms-thedeadly-costs-of-a-war-on-cops/; and Howard Safir, "Police Commissioner: Bad Old Days of Crime May Be Back," Time, June 5, 2015, https.://time.com/3908254/howard-safir-crime/.

138 Michael D. White, "Ambush Killings of the Police, 1970-2018: A Longitudinal Examination of the 'War on Cops' Debate," Police Quarterly 23, no. 4 (2020): 451-71, https://doi.org/10.1177/1098611120919441.

139 "Letter from National FOP President Canterbury to President Obama," Baltimore County Fraternal Order of Police, Feb. 13, 2016. http://foplodge4.org/letter-from-national-fop-president-canterbury-to-presidentobama/. 140 MacDonald, War on Cops, 3.
} 
However, most empirical research casts doubt on claims that a war on police is ongoing. ${ }^{141} \mathrm{FBI}$ annual reports on officers killed by felonious acts found 48 such incidents in 2019, a decrease from 55 in 2010.142 While there may be more than one explanation for this decline, it is consistent with the broader downward trend since 1973. With the exception of a rise to 72 in 2011 and a sharp decline in 2013 to 27, the number of officers killed by a felonious act each year has ranged from 46 to 66 , with no clear pattern. In addition, a report by the Department of Justice indicates that "there are substantial differences in the extent of risk for officers across comparable cities and counties," based on local conditions. ${ }^{143}$

Sierra-Arévalo observes that the danger imperative framework provides a powerful filter through which police interpret information, leading them to view their work as dangerous despite data to the contrary:

That policing is growing statistically safer over time is of little consequence to officers on patrol, particularly if they or their fellow officers have been direct or vicarious victims of violence. What matters is the collective perception of police work as dangerous, and the shared expectation of officers to protect themselves and one another from violence. ${ }^{144}$

A pervasive perception among police is that they need to be more heavily armed because they are in an arms race with criminals; active-shooter and hybrid targeted violence incidents now pose a greater risk to ordinary police officers; and the police need to defend themselves from an escalating "war on cops." However, empirical evidence does not suggest that this perception is accurate. Nevertheless, it has become an article of faith in most police departments and among most officers.

\section{Assessing Cultural Militarization}

The cultural dimension of militarization involves incorporating military beliefs and values into the conception of the police officer's role. This is most evident in the notion that police are engaged in a war on drugs and terror, and that police must defend themselves in

\footnotetext{
${ }^{141}$ For claims that no such war exists, see, Tate Fegley, "The War on Cops: Where's the Evidence?" Mises Wire, Jan. 22, 2018, https://mises.org/wire/war-cops-wheres-evidence; Edward R. Maguire, Justin Nix, and Bradley A. Campbell, "A War on Cops? The Effects of Ferguson on the Number of U.S. Police Officers Murdered in the Line of Duty," Justice Quarterly 34, no. 5 (2017): 739-58, https://doi.org/10.1080/07418825.2016.1236205; and Ed Krayewski, "There Is Still No War on Cops," Reason, July 19, 2016, https://reason.com/2016/07/19/there-is-still-no-war-on-cops/. For qualified skepticism, see, White, "Ambush Killings of the Police."

${ }^{142}$ See, "Law Enforcement Officers Killed and Assaulted (LEOKA)," Federal Bureau of Investigation, https://www.fbi.gov/services/cjis/ucr/publications\#LEOKA, for 2019 and 2010.

${ }_{143}$ Joseph B. Kuhns et al., Understanding Firearms Assaults Against Law Enforcement Officers in the United States, Office of Community Oriented Policies, 2016, 3.

${ }^{144}$ Sierra-Arévalo, "American Policing," 14.
} 
a war that is being waged against them. Cultural militarization is reflected more subtly in the belief that police must engage in aggressive preventive operations, which can lead them to regard certain persons, especially members of minority groups, as outsiders - as suspects or enemies rather than fellow citizens. All of this contributes to a growing conception in recent years that the work of police officers more closely resembles the work of the military.

The result is that a police officer now may see himself as a soldier patrolling a theater of conflict who must be alert to the presence of enemies and suspected hostiles. This can lead him to construe ambiguous behavior as threatening and to resolve uncertainty by using lethal force to defend himself. This may occur especially when an officer confronts a member of a minority group. Greater interaction between police and individuals due to aggressive preventive policing therefore may increase the likelihood of violent confrontations.

\section{THE MATERIAL DIMENSION OF MILITARIZATION}

In this section, I examine those material dimensions of militarization that have become most prominent in the public eye: the expansive deployment of police paramilitary units, such as SWAT teams, and the acquisition of military equipment by police. Research indicates a striking increase in the percentage of police departments that have paramilitary units since the 1980s. These units overwhelmingly are used to serve drug warrants, rather than to respond to hostage, siege, or active-shooter situations. While there is a paucity of empirical research on the topic, the studies that do exist conclude that the use of paramilitary units has no appreciable effect on crime. Data also indicate a substantial increase since the 1990s in police departments with military equipment. Research on the effects of acquiring such equipment draws mixed conclusions, but most studies indicate that it does not affect crime rates. Finally, there are indications that paramilitary units are used more frequently in minority communities, and some studies suggest a relationship between the acquisition of military equipment and the percentage of racial and ethnic minorities in a community.

\section{Police Paramilitary Units}

Scope

A prominent example of police militarization in the public mind is the use of police paramilitary units, exemplified by SWAT teams. These were first established in Philadelphia in 1964, but were refined by the Los Angeles Police Department in response to 
the Watts riots in 1965. ${ }^{145}$ The Los Angeles Police Department asked the military to help train these units, which were explicitly modeled on military special operations forces. Other jurisdictions soon established their own SWAT teams, whose responsibility was to respond to riots, hostage situations, barricaded suspects, and terrorist attacks. ${ }^{146}$

Data on SWAT teams are hard to find. Maryland provided information on SWAT activities from 2011 to 2014 , but legislation requiring such disclosure expired. ${ }^{147}$ Utah now is the only state that reports on these operations. The percentage of cities with populations of 50,000 or more with SWAT teams is estimated to have increased from 59 percent in 1982 to 89 percent in 1995, while the percentage of towns with populations between 25,000 and 50,000 with SWAT teams increased from 26 percent in 1984 to 80 percent in 2005.148 Peter Kraska and Shannon Williams estimate that in the early 1980s there were about 3,000 SWAT team deployments, and that by 2011 there were approximately $60,000 .{ }^{149}$ A survey of SWAT team activity in 254 police departments of all sizes found that over 60 percent of departments had their own SWAT team in 2013. ${ }^{150}$ The number of calls deemed to require deployment of a SWAT unit was fairly steady between 2009 and 2013, with the mean number of calls around 8,000 and the mode around 3,100.151

The most striking aspect of SWAT team deployments is their extensive use beyond the limited situations for which they were created. The vast majority of deployments involve warrant enforcements for drug searches. One study that analyzed Maryland data from 2011 to 2014 found that about 90 percent of the 8,244 SWAT deployments in that four-year period were to serve search warrants. ${ }^{152} \mathrm{~A}$ study by the American Civil Liberties Union of over 3,800 SWAT deployments from 2011 to 2012 found that 79 percent involved home searches and more than 60 percent involved searches for drugs. Only 7 percent were

\footnotetext{
145 Radley Balko, Rise of the Warrior Cop: The Militarization of America's Police Forces (New York: Public Affairs, 2014), 53.

146 Kraska and Kappeler, "Militarizing American Police," 4.

147 The data can be found at, "SWAT Team Reporting - SB 447," the Maryland Governor's Office on Crime Prevention, Youth, and Victim Services, accessed Nov. 25, 2020, http://goccp.maryland.gov/reportspublications/law-enforcement-reports/swat/.

148 Balko, Rise of the Warrior Cop, 53. Kraska and Louis Cubellis surveyed departments with fewer than 100 officers in towns of the same size and found that 25.6 percent had SWAT units in 1980, which increased to 52.1 percent in 1990. Peter B. Kraska and Louis J. Cubellis, "Militarizing Mayberry and Beyond: Making Sense of American Paramilitary Policing," Justice Quarterly 14, no. 4 (1997): 607-29, https://doi.org/10.1080/07418829700093521.

149 Kraska and Williams, "The Material Reality of State Violence," 148.

150 National Special Weapons and Tactics (SWAT) Study: A National Assessment of Critical Trends and Issues from 2009 to 2013, International Association of Chiefs of Police and the National Tactical Officers Association, 2013, vi, https://www.theiacp.org/sites/default/files/2018-10/swatstudy.pdf.

151 National Special Weapons and Tactics (SWAT) Study, 7.

152 Jonathan Mummolo, "Militarization Fails to Enhance Police Safety or Reduce Crime but May Harm Police Reputation," Proceedings of the National Academy of Sciences of the United States of America 115, no. 37 (2018): 9182, https://doi.org/10.1073/pnas.1805161115.
} 
for hostage, barricade, or active-shooter scenarios. ${ }^{153}$ Since Utah began providing reports in 2014, between 77 and 83 percent of SWAT deployments have been to execute drug warrants. 154

Research by Kraska and Kappeler on the use of paramilitary units by almost 550 law enforcement agencies between 1980 and 1995 indicates that this trend began in the 1980s. ${ }^{155}$ Between 1980 and 1983, the mean number of deployments was 13 per year, or about one a month. The number more than doubled by 1986, almost tripled by 1989 , and quadrupled by 1995 . Of the almost 200 departments that had had paramilitary units since 1980, and that provided complete data for the period, activity increased by 538 percent. ${ }^{156}$ For all departments in the study in 1995, there were 25,201 deployments - "high risk warrant work" (mostly "drug raids") accounted for 75.9 percent of these, while barricaded persons accounted for 13.4 percent, hostage situations for 3.6 percent, civil disturbances for 1.3 percent, and terrorist incidents for .09 percent. 157

Police serving a warrant are required by law to knock on the door, announce their presence, and wait for an answer. They may obtain a "no-knock" warrant, however, if they have reasonable suspicion that advance notice would risk a violent response or allow destruction of evidence. The Supreme Court has held, however, that even when police should have announced their presence but did not, any evidence seized in the search may be introduced at trial. ${ }^{158}$ No-knock search warrants are allowed in every state except Oregon, where they are prohibited by state law, and in Florida, where they are banned under a state Supreme Court decision.

There is reason to believe that a considerable number of drug or gun raids involve forcible entry. The American Civil Liberties Union study of SWAT deployments concluded that forcible entry likely occurred in 65 percent of drug searches. ${ }^{159}$ Utah reports that between 45 and 61 percent of entries have been forcible since 2014.160 One recent ethnographic study of SWAT team drug operations by Brian Schaefer in a city he calls "Bourbonville" found that there was little difference in practice between a raid in which police announced their presence and a no-knock raid. Of the 73 warrants served from April 2013 through September 2014, every entry involved using a battering ram to break down the door:

\footnotetext{
153 War Comes Home: The Excessive Militarization of American Policing, American Civil Liberties Union, June 2014, 31, https://www.aclu.org/sites/default/files/field document/jus14-warcomeshome-text-rel1.pdf. 154 "Law Enforcement Transparency Reporting in Utah: 2018 Annual Report," Utah Commission on Criminal and Juvenile Justice, 2018, https://justice.utah.gov/Documents/CCIJ/LETR/2018\%20LET\%20Annual\%20Report.html.

155 Kraska and Kappeler, "Militarizing American Police," 1, 6-9.

156 Kraska and Kappeler, "Militarizing American Police," 6-7.

157 Kraska and Kappeler, "Militarizing American Police," 7.

158 Hudson v. Michigan, 547 U.S. 586 (U.S.C. 2006).

159 War Comes Home, 38.

160 "Law Enforcement Transparency Reporting in Utah."
} 
The detectives announce their presence and purpose in conjunction with the first hit on the door. A detective explained, "As long as we announce our presence, we are good we don't want to give them any time to destroy evidence or grab a weapon, so we go fast and get through the door quick." 161

According to Radley Balko, the typical SWAT team operates with military-style clothing, including camouflage, and equipment, which includes "Kevlar helmets and vests; gas masks, knee pads, gloves, communication devices, and boot knives; and military-grade weapons, such as the Heckler and Koch MP5 submachine gun." 162 When teams conduct raids, they do so at night or just before dawn. In these operations, police usually break down the door with a battering ram or explosives, sometimes detonate a flashbang grenade to stun the occupants, and instruct everyone inside to remain in the prone position at gunpoint. 163

Balko suggests that drug raids can create scenarios in which alarmed residents may use a weapon, leading police to believe it is necessary to use lethal force to defend themselves. ${ }^{164}$ A New York Times study of SWAT team drug raids from 2010 to 2016 found that 81 civilians and 13 law enforcement officers died during such operations, although it did not describe the circumstances under which the deaths occurred nor did it indicate the number of incidents that it reviewed. 165

It was a no-knock drug raid that resulted in the highly publicized death of Breonna Taylor in Louisville in March 2020. Three Louisville police officers executing a no-knock warrant shortly after midnight used a battering ram to force open Taylor's front door. Police said that they knocked several times and announced themselves without getting an answer before they forcibly entered. Taylor's boyfriend Kenneth Walker said that he and Taylor heard knocking, asked who it was, and got no response. ${ }^{166}$ When police entered, Walker drew his gun and fired. In the ensuing gunfire, Taylor was shot eight times and a Louisville police officer was injured. In records of Walker's emergency 911 call that were

\footnotetext{
161 Brian Patrick Schaefer, "Knocking on the Door: Police Decision Points in Executing Search Warrants," University of Louisville Electronic Theses and Dissertations (2015), 128.

162 Radley Balko, Overkill: The Rise of Paramilitary Police Raids in America (Washington, DC: Cato Institute, 2006), 5, https://www.cato.org/publications/white-paper/overkill-rise-paramilitary-police-raidsamerica\#downloads.

163 Balko, Overkill, 5.

164 Balko, Overkill, 35.

165 Kevin Sack, “Door-Busting Drug Raids Leave a Trail of Blood,” New York Times, March 18, 2017, https://www.nytimes.com/interactive/2017/03/18/us/forced-entry-warrant-drug-raid.html.

166 Darcy Costello and Tessa Duvall, “'Clearly, I Was Scared’: Newly Released Police Interviews Shed Light on Breonna Taylor Case," Louisville Courier-Journal, May 25, 2020, https://www.courierjournal.com/story/news/politics/metro-government/2020/05/23/breonna-taylor-shooting-policeinterviews-reveal-new-details/5246096002/.
} 
released afterward, Walker said, "I don't know what happened ... somebody kicked in the door and shot my girlfriend."167

A 2008 study of SWAT team deployments from 1986 to 1998, however, found that "perhaps the most notable aspect of the deadly force findings is that SWAT officers rarely discharge their firearms at human targets." 168 The survey found that, across tens of thousands of operations, only 342 involved gunfire. In those operations, SWAT team fire struck almost 200 citizens, killing 139 of them. ${ }^{169}$ Similarly, Jonathan Mummolo's study of 8,244 SWAT deployments in Maryland found that nine civilians died, representing 0.11 percent of the deployments. ${ }^{170}$ Another study found no difference between SWAT officers and regular officers in the frequency with which they used force. ${ }^{171}$ Utah data indicate that, in 2,370 deployments from 2014 to 2018, suspects brandished weapons in 85 cases, officers fired shots in 14 cases, and there were five civilian deaths and one officer death. ${ }^{172}$ Unfortunately, information is not available about the specific circumstances in which police fired weapons or individuals died.

Notwithstanding these figures, SWAT raids are extremely violent events that involve the use of weapons and tactics associated more with military operations than police work. The message is that police are agents of the state authorized to use intense violence against anyone who poses a threat, and that everyone in the home is a suspect and ongoing force can be used if they do not fully comply with orders. This type of operation, and the assumptions that underlie it, is characteristic of the use of military force against enemies - not law enforcement activities to protect fellow citizens.

Finally, a prominent feature of SWAT operations is their frequent deployment in African American communities, even after controlling for crime rates. ${ }^{173}$ The American Civil Liberties Union's study of SWAT operations found that 42 percent of SWAT search warrants were for African Americans suspects and 12 percent were for Latino suspects. ${ }^{174}$ Of all persons affected by SWAT raids in drug cases, 61 percent were from minority communities. ${ }^{175}$

\footnotetext{
167 Victoria Albert, "911 Call from Breonna Taylor's Shooting Death Released: 'Somebody Kicked in the Door and Shot my Girlfriend,"' CBS News, May 29, 2020, https://www.cbsnews.com/news/breonna-taylorkenneth-walker-911-call-police-shooting/.

${ }_{168}$ David A. Klinger and Jeff Rojek, "Multi-Method Study of Special Weapons and Tactics Teams," National Criminal Justice Reference Service, August 2008, 7, https://www.ncjrs.gov/pdffiles1/nij/grants/223855.pdf. ${ }^{169}$ Klinger and Rojak, "Multi-Method Study," 7. The study also found that 379 individuals killed themselves during these operations.

170 Mummolo, "Militarization Fails," 9182.

171 Jimmy J. Williams and David Westall, "SWAT and non-SWAT Police Officers and the Use of Force," Journal of Criminal Justice 31, no. 5 (September/October 2003): 469-474, https://doi.org/10.1016/S00472352(03)00051-5.

172 "Law Enforcement Transparency Reporting in Utah."

173 Mummolo, "Militarization Fails," 9181.

174 War Comes Home, 5.

175 War Comes Home, 5.
} 
SWAT team operations thus have grown beyond the originally envisioned high-risk scenarios to encompass what some regard as routine police work. The American Civil Liberties Union maintains, "The use of the SWAT team to execute a search warrant essentially amounts to the use of paramilitary tactics to conduct domestic criminal investigations and searches of people's homes."176 Similarly, Kraska argues that the use of SWAT teams has "normaliz[ed] itself into a range of proactive and mainstream police functions."177

Kraska regards this as an unwarranted expansion of the definition of a high-risk situation calling for specialized expertise outside conventional police operations. On the other hand, Schaefer notes that the detectives in his study of drug raids "refer to the often violent tendencies of the people targeted by this group, and the violent background as a key factor in the use of police raids. This line of thought follows the increasing logic that criminals are becoming well-armed, making the detectives job more dangerous than ever."178

Assessing these claims is difficult in light of the available information on SWAT team operations, which simply lists these teams as serving warrants without distinguishing between high-risk and routine, low-risk situations. Calls for greater disclosure about these operations should include more information about this level of detail. Even if such information were available, however, it would not indicate the evidence on the basis of which a raid is characterized as high risk. This suggests that an important means of ensuring accountability for SWAT operations is judicial scrutiny of warrant requests.

\section{Effects of Creating and Deploying Paramilitary Units}

How effective has the increased use of SWAT teams been in meeting law enforcement goals? To date, there is sparse empirical research on this question because of the lack of information on these operations. Mummolo reviewed national data on 9,000 law enforcement agencies and on Maryland's use of SWAT teams to assess the effect on violent crime and police officer safety. ${ }^{179}$ For the national study, he analyzed the effect of acquiring a SWAT unit, while for Maryland he assessed the impact of SWAT deployments in general and for barricade situations specifically. He found that there were no statistically significant effects in either case on violent crime or officer safety. ${ }^{180}$

Scott Phillips, Andrew Wheeler, and Dae-Young Kim evaluated the effects of 39 police paramilitary unit raids during a two-day period in Buffalo in 2012. ${ }^{181}$ They measured

\footnotetext{
176 War Comes Home, 3.

177 Kraska, "Militarization and Policing," 508.

178 Schaefer, "Knocking on the Door," 67.

179 Mummolo, "Militarization Fails."

180 Mummolo, "Militarization Fails," 9181.

181 Scott Phillips, Andrew Wheeler, and Dae-Young Kim, "The Effect of Police

Paramilitary Unit Raids on Crime at Micro-places in Buffalo, New York," International
} 
effects by changes in calls for police service, drug arrests, and Part 1 crimes as designated by the FBI, which are the most serious. They found that calls for service, arrests, and nonviolent Part 1 crimes increased in locations with raids compared to similar locations, and that there was no statistically significant effect on violent Part 1 crimes. They did find evidence of a slight decline in all types of Part 1 crimes two weeks after an intervention, suggesting that, at best, police paramilitary unit raids have a "short-term deterrent effect on crime."182 The absence of any significant deterrent effect led the authors to conclude that "using [SWAT raids] as a part of a strategic policy of crime reduction will have limited success." 183

Another study by Kim, Phillips, and Wheeler analyzed the same dataset on the city level and used a different time interval to measure the effect of paramilitary intervention. ${ }^{184}$ It found that the impact of intervention was greatest for property crimes such as robberies and larcenies. This impact lasted for some time and then diminished gradually. On the other hand, violent crimes did not decline nearly as much as property crimes, and rape increased significantly during the post-intervention period. Given a "quickly decaying deterrent effect" of these raids, the authors suggested that long-term crime deterrence should be based on "more holistic" approaches "beyond strictly enforcement based responses," including community policing. ${ }^{185}$

\section{Military Equipment}

\section{Acquisition of Equipment}

The most visible indications of militarization are military clothing and equipment used by police forces. There are 12 different government programs overseen by federal agencies that are authorized to provide law enforcement agencies with military equipment. ${ }^{186}$ The Department of Homeland Security furnishes the most funding to law enforcement agencies for military equipment, providing $\$ 4.1$ billion in grants for the Law

\footnotetext{
Journal of Police Science and Management 18, no. 3 (2016): 206-19, https://doi.org/10.1177\%2F1461355716660568.

182 Phillips, Wheeler, and Kim, "The Effect of Police Paramilitary Unit Raids," 206.

183 Phillips, Wheeler, and Kim, "The Effect of Police Paramilitary Unit Raids," 216.

184 Dae-Young Kim, Scott W. Phillips, and Andrew P. Wheeler, "Using 'Symbolic' SWAT Raids as a Crime Reduction Strategy: Are Their Effects 'Instrumental' in Nature?” Criminal Justice Policy Review 30, no. 2 (2019): 176-200, https://doi.org/10.1177\%2F0887403416664567.

185 Kim, Phillips, and Wheeler, “Using 'Symbolic' Swat Raids,” 198.

186 Mark Denbeaux et al., "Costs and Consequences of Arming America's Law Enforcement with Combat Equipment," Seton Hall Public Law Research Paper No. 2492321, 2014,

https://papers.ssrn.com/sol3/papers.cfm?abstract id=2492321.
} 
Enforcement Terrorism Prevention Activities program from 2008 to 2015, although not all of this was for military equipment. ${ }^{187}$

However, the program that has attracted the most public attention is the Section 1033 program operated by the Department of Defense, which supplies surplus military equipment to law enforcement agencies. This began with Section 1208 of the National Defense Authorization Act for Fiscal Years 1990 and 1991, which authorized the secretary of defense to transfer military equipment, including small arms and ammunition, for use in drug interdiction by state and local law enforcement agencies. ${ }^{188}$ Legislation in 1997 enabled local agencies to use equipment for any law enforcement purpose, giving priority to drug enforcement. ${ }^{189}$ After the Sept. 11, 2001 attacks, counter-terrorism also became a prominent mission furthered by the program. Law enforcement agencies receive the equipment at little or no cost, but they must use the equipment within a year or send it back. It is not hard to see how this could lead police to use military equipment in some instances in which it is not necessary.

In response to public concern about police militarization in the wake of the incidents in Ferguson, Obama created a working group in January 2015 to consider reform of the 1033 program. The group called for creating lists of "prohibited equipment" that could no longer be distributed to police and "controlled equipment" that could only be provided in response to a demonstrated need. ${ }^{190}$ The "prohibited equipment" included tracked armored vehicles and weaponized vehicles of any kind, rifles and ammunition of .50-caliber or higher, and grenade launchers. The "controlled equipment" included any specialized firearms, manned and unmanned aircraft, explosives, and riot gear. In 2016, the Defense Department began recalling previously issued surplus gear that had been placed on the prohibited equipment list. In August 2017, however, Trump eliminated all restrictions on the transfer of military equipment to law enforcement agencies. ${ }^{191}$

The latest information from the Defense Logistics Agency's Law Enforcement Support Office, which administers the 1033 program, indicates that $\$ 7.2$ billion of

\footnotetext{
187 “Fiscal Year 2008-2015 Law Enforcement Terrorism Prevention Activity Funding," Department of Homeland Security, Sept. 29, 2016, https://www.fema.gov/media-library-data/147510308896941d58a2adf314fc43775eff29fdce147/FY 2008-2015 LETPA Funding.pdf. 188 "National Defense Authorization Act for Fiscal Years 1990 and 1991," Pub. L. No. 101-189, 103 Stat. 1566, Title XII, sec. 1208, 101st Congress, https://www.congress.gov/bill/101st-congress/house-bill/2461/text. 189 “National Defense Authorization Act for Fiscal Year 1997," Pub. L. No. 104-201, 110 Stat. 2639, Title X, sec. 1033(a)(1) in Division A, Subtitle B, 104th Congress, https://www.congress.gov/bill/104th-congress/housebill/3230.

190 "Federal Support for Local Law Enforcement Equipment Acquisition," Exec. Order No. 13688, Federal Register 80, no. 14, (Jan. 16, 2015): 3451, https://www.govinfo.gov/content/pkg/FR-2015-01-22/pdf/201501255.pdf.

${ }^{191}$ Adam Goldman, "Trump Reverses Restrictions on Military Hardware for Police," New York Times, Aug. 28, 2017, https://www.nytimes.com/2017/08/28/us/politics/trump-police-military-surplus-equipment.html.
} 
equipment has been transferred to law enforcement agencies since its inception, and that more than 8,000 law enforcement agencies have participated in the program. ${ }^{192}$

A challenge in conducting research on the 1033 program has been that there was limited public information available about it until 2014. Moreover, a May 2020 paper by Kenneth Lowande maintains that prior research, both before and after 2014, is based on inaccurate data that do not take into account military equipment returned or destroyed, and conflates transfers between local agencies with new distributions from the Defense Department. ${ }^{193}$ This suggests taking some caution in evaluating the findings from research that does not account for these things.

One study by David Ramey and Trent Steidley found that, between 1995 and 2016, participating local agencies received an annual average amount of almost $\$ 80,000$ in equipment per 10,000 persons, including about $\$ 26,500$ of militarized property and about $\$ 52,700$ of non-militarized property. ${ }^{194}$ More than half the requests from departments were for drug enforcement operations. ${ }^{195}$ A 2016 study indicated that the percentage of the U.S. population residing in a jurisdiction in which the police department had received any military equipment from the 1033 program increased from 15 percent in 2009 to 29 percent in 2014.196

Steven Radil, Raymond J. Dezzani, and Lanny D. McAden calculated that, from 2006 through 2013, approximately 2.3 million pieces of equipment were transferred to counties, at an estimated value of $\$ 1.5$ billion, with 80 percent of all U.S. counties receiving some equipment. 197 Vehicles accounted for about $\$ 900$ million of the $\$ 1.5$ billion, with "miscellaneous" items coming to just under $\$ 390$ million. ${ }^{198}$ Since other categories include weapons, armored vehicles, communications and surveillance equipment, and personal protective equipment, the figures indicate that many of the items transferred are not for tactical military purposes. A report in June 2020 estimates that, as of March 2020, local law

\footnotetext{
192 See, “Law Enforcement Support Office,” Defense Logistics Agency, Defense Logistics Agency, accessed July 3, 2020, https://www.dla.mil/DispositionServices/Offers/Reutilization/LawEnforcement.aspx.

193 Kenneth Lowande, "Police Demilitarization and Violent Crime," Nature Human Behavior (2020). https://doi.org/10.1038/s41562-020-00986-6.

194 David Ramey and Trent Steidley, "Policing through Subsidized Firepower: An Assessment of Rational Choice and Minority Threat Explanations of Police Participation in the 1033 Program," Criminology 56, no. 4 (2018): 812, 827, https://doi.org/10.1111/1745-9125.12193. Militarized property was defined as equipment that makes agencies "more capable of participating (and dominating) in violent confrontations." These include "military grade communications and transportation equipment, military fatigues, firearms, and ordinance [sic] preferred by modern militaries." See page 814 .

195 Ramey and Steidley, "Policing through Subsidized Firepower," 823.

196 Federico Masera, "Bringing War Home: Violent Crime, Police Killings and the Overmilitarization of the US Police," unpublished manuscript, 2016, https://papers.ssrn.com/sol3/papers.cfm?abstract id=2851522.

197 Steven M. Radil, Raymond J. Dezzani, and Lanny D. McAden. "Geographies of U.S. Police Militarization and the Role of the 1033 Program," Professional Geographer 69, 2 (2017): 203-213, https://doi.org/10.1080/00330124.2016.1212666.

198 Radil, Dezzani, and McAden, “Geographies of U.S. Police,” 209.
} 
enforcement agencies had received more than $\$ 850$ million of equipment through the program since the events in Ferguson in 2014. ${ }^{199}$

Research examining the geographical distribution of 1033 program equipment found that there were small clusters of high per capita acquisitions in the Southeast (especially in Tennessee and Alabama), the Southwest, and Montana. ${ }^{200}$ The authors suggest that this indicates the need to analyze how increasing police militarization reflects perceived law enforcement needs based on local conditions. The study also found that the acquisition of equipment mildly correlated with more populated jurisdictions, except for weapons, for which population size was negatively correlated. ${ }^{201}$ The study concluded that police militarization through the 1033 program "is not likely to be a phenomenon restricted to large urban police departments."202

Zach Baumgart drew on publicly available data from the Law Enforcement Management and Administrative Statistics survey, a data set on acquisition of equipment by 4,000 police departments from 1990 to 2007, to construct an index of militarization based on three dimensions: amount of military equipment, use of paramilitary tactics, and focus on military-style policing. ${ }^{203} \mathrm{He}$ emphasized that militarization should be conceptualized on a continuum, rather than as a dichotomous characteristic. ${ }^{204}$ His study concluded that, controlling for relevant variables, there was a steady increase in militarization in these departments over that period. Baumgart noted an emerging convergence among departments, such that departments that were relatively militarized in 1990 increased their rate of militarization slowly, while departments that were less militarized in 1990 increased at a faster rate. ${ }^{205} \mathrm{He}$ concluded that the evidence indicates that police departments are becoming comparable in their level of militarization, "such that the militarized department simply becomes 'the police' in the next few decades."206

Several scholars have suggested that the militarization of police departments may be related to the racial and ethnic composition of the areas that they serve. The study by Ramey and Steidley found that, while violent crime rates predicted some of the likelihood of acquiring military equipment, the perception that members of minority communities pose a threat played a significant role in militarization. This is known as the "minority

\footnotetext{
199 John Templeton, "Police Departments Have Received Hundreds Of Millions Of Dollars In Military Equipment Since Ferguson," BuzzFeed News, June 4, 2020, https://www.buzzfeednews.com/article/johntemplon/police-departments-military-gear-1033-program. 200 Radil, Dezzani, and McAden, “Geographies of U.S. Police,” 208.

201 Radil, Dezzani, and McAden, “Geographies of U.S. Police,” 209.

202 Radil, Dezzani, and McAden, “Geographies of U.S. Police,” 209.

203 Zach Baumgart, "From Copper to Steel: Police Militarization at the End of the 20th Century," working paper, 2016, 2, http://dx.doi.org/10.31235/osf.io/m7j3v.

204 Baumgart, "From Copper to Steel," 16.

205 Baumgart, "From Copper to Steel," 44.

206 Baumgart, "From Copper to Steel," 44.
} 
threat" theory. ${ }^{207}$ Controlling for other variables, "[d]epartments in places with larger black populations are more likely to acquire militarized property through the 1033 program." 208 Furthermore, "[f]or those departments that successfully acquire militarized property ... [t]here is a nonlinear exponential relationship between the respective black and Hispanic populations" and the value of military equipment acquired. In other words, the rate of increase in the value of such equipment is considerably greater than the rate at which the black and Hispanic populations increase. ${ }^{209}$

The study found that, controlling for other potentially relevant variables, the relationship between minority threat and participation in the 1033 program was statistically significant for acquisitions of militarized, but not non-militarized, equipment. 210 That is, as the relative size of the minority population increases, police are more likely to acquire militarized equipment. ${ }^{211}$ The authors conclude that this finding provides support for the claim that police acquisition of combat equipment is in part a product of the perception that racial and ethnic minorities pose a threat to the community. ${ }^{212}$

A study by Olugbenga Ajilore provides mixed support for the minority threat theory. ${ }^{213}$ It found that counties with a higher proportion of African Americans were less likely to acquire Mine-Resistant Ambush Protected vehicles, but counties with greater ethnic residential segregation were more likely to acquire them. As Ajilore concludes, "racial inequalities persist even when minority populations move to the suburbs, and corresponding police militarization is one such example of this phenomenon."214

\section{Effects of Acquiring Equipment}

Research on the effects of acquiring military equipment is still in its early stages, but the number of studies has been increasing in recent years. ${ }^{215}$ It is important to remember Lowande's word of caution in assessing these studies. Nevertheless, their findings are suggestive, especially since many arrive at similar conclusions that cast doubt on the value of acquiring and using such equipment. Two studies that found positive effects of acquiring

\footnotetext{
207 See, Stephanie L. Kent and David Jacobs, "Minority Threat and Police Strength from 1980 to 2000: A Fixedeffects Analysis of Nonlinear and Interactive Effects in Large U.S. Cities," Criminology 43, no. 3 (2005): 73160, https://doi.org/10.1111/j.0011-1348.2005.00022.x.

208 Ramey and Steidley, "Policing through Subsidized Firepower," 838.

209 Ramey and Steidley, "Policing through Subsidized Firepower," 838.

210 Ramey and Steidley, "Policing through Subsidized Firepower," 839. Militarized equipment includes items such as weapons, armored trucks, helicopters, night-vision goggles, and fatigues.

211 Ibid.

212 Ibid.

213 Olugbenga Ajilore, “The Militarization of Local Law Enforcement: Is Race a Factor?” Applied Economics Letters 22, no. 13 (2015): 1089, https://doi.org/10.1080/13504851.2014.1002884.

214 Ajilore, "Militarization of Local Law Enforcement," 1092.

215 Sam Bieler, "Police Militarization in the USA: The State of the Field," Policing 39, no. 4 (2016): 586-600, https://doi.org/10.1108/PIJPSM-03-2016-0042.
} 
paramilitary equipment through the 1033 program were cited by Trump when he eliminated restrictions on the transfer of military equipment to law enforcement agencies, but their findings have been challenged recently.

One common way that scholars measure militarization is the value of military equipment acquired by police departments. A study by Vincenzo Bove and Evelina Gavrilova, for instance, analyzed equipment transfers to 8,000 local police agencies at the county level from 2006 to $2012 .{ }^{216}$ It found that a 10 percent increase in the value of military equipment acquired led to a drop in the number of crimes of 5.9 per 100,000 persons. This included a decrease in robberies, assaults, burglaries, larcenies, and motor vehicle thefts. The authors found an insignificant effect on homicides. Moreover, receipt of military equipment did not affect the number of calls police received, the number of police officers assaulted or injured in the line of duty, or the number of offenders killed by the police.

The authors also found that acquired "gears and vehicles" had "strong and sizable effects on all the types of crime." 217 They note that both these categories of equipment are easily observable, and suggest that their contribution to a decline in crime is consistent with the theory of "perceptual deterrence" based on reinforcement of a sense of police authority and legitimacy. ${ }^{218}$

A study by Matthew Harris et al. also examined the receipt of 1033 equipment by counties, focusing on the effects of acquiring military vehicles and tactical weapons. ${ }^{219}$ It found that a 1 percent increase in the number of tactical items reduced gun assaults on police officers by 0.1 percent and decreased the probability of gun assaults on officers by 0.03 percent. Acquisition of vehicles had the largest effect on gun assaults, with a 10 percent increase leading to a 3.5 percent decrease in assaults on police. ${ }^{220}$ The study also found that receiving tactical equipment reduced the probability that an officer would be killed in the line of duty. ${ }^{221}$ In addition, a 1 percent increase in tactical items led to a 0.25 percent increase in arrests for drug sales and a 0.23 percent increase in arrests for drug possession. The authors did note, however, "We do find that tactical items lead to increased arrests for petty offenses, which raises some concern about more aggressive policing."222

\footnotetext{
${ }^{216}$ Vincenzo Bove and Evelina Gavrilova, "Police Officer on the Frontline or a Soldier? The Effect of Police Militarization on Crime," American Economic Journal: Economic Policy 9, no. 3 (August 2017): 1-18, https://doi.org/10.1257/pol.20150478.

217 Bove and Gavrilova, "Police Officer on the Frontline or a Soldier?" 14. They define "gears" as communication devices, special clothing, and night-vision equipment. See page 5.

${ }^{218}$ Bove and Gavrilova, "Police Officer on the Frontline or a Soldier?" 14.

${ }^{219}$ Matthew C. Harris et al., "Peacekeeping Force: Effects of Providing Tactical Equipment to Local Law Enforcement," American Economic Journal: Economic Policy 9, no. 3 (August 2017): 291-313, https://doi.org/10.1257/pol.20150525. The authors included firearms, optics, night optics, grenade launchers, trucks, aircraft, armored personnel carriers, and mine-resistant vehicles in the category of tactical equipment.

${ }^{220}$ Harris et al., "Peacekeeping Force," 305.

${ }^{221}$ Harris et al., "Peacekeeping Force," 306.

222 Harris et al., "Peacekeeping Force," 307.
} 
The authors also found that a 1 percent increase in tactical equipment led to a 0.27 percent decrease in complaints against police, ${ }^{223}$ and did not affect the number of deaths caused by police. 224

A recent paper challenges the findings in these two studies, based on an analysis of individual law enforcement agencies rather than counties as a whole.225 Gunderson et al. note that, at the time of the research by Bove and Gavrilova and by Harris et al., the Department of Defense provided information on equipment transfers only at the county level. It did not begin identifying local law enforcement agency recipients until 2018. They argue that aggregating data at the county level obscures differences between agencies within a given county, which may result in inaccurate inferences about the effects of acquiring military equipment.

Gunderson et al. replicated the analyses done by Bove and Gavrilova and by Harris et al. on the agency level, using the same model and estimation strategy for each study. Their results differed significantly from those in both studies. With respect to Bove and Gavrilova, they concluded, "[W]e either find no significant effect of military aid on a variety of crime rates, or we find a significant and positive effect, as with the total crime rate variable."226 In addition, Gunderson et al. replicated the Bove and Gavrilova analysis on the county level after adjusting for several inconsistencies between data previously released by the Defense Department and currently available data. They found the same result as in their analysis of individual law enforcement agencies. As a result, they declared, "We therefore cannot conclude definitively that military aid exerts any influence on crime rates, either at the county or at the agency level."227

Gunderson et al. conducted the same replication of the study by Harris et al. on the county and agency levels. Their analysis focused on the extent to which receiving military equipment affects rates of homicide, robbery, assault, and vehicle theft. They found no statistically significant effect on the rates of any of these crimes. ${ }^{228}$ On the county level, they did find an effect on homicide and assault rates. They noted, however, that these results reversed when disaggregated to the individual agency level, which reinforces the concern about the potential for misleading results when conducting analysis on the county level. ${ }^{229}$

\footnotetext{
223 Harris et al., "Peacekeeping Force," 305.

224 Harris et al., "Peacekeeping Force," 305.

225 Anna Gunderson et al., "Does Military Aid to Police Decrease Crime? Counterevidence from the Federal 1033 Program and Local Police Jurisdictions in the United States," paper presented at the Annual Meeting of the American Political Science Association, Boston, MA, 2018, and the Benefits and Costs of Policing Symposium, New York University School of Law, 2018, https://statmodeling.stat.columbia.edu/wpcontent/uploads/2019/04/Militarization.pdf.

226 Gunderson et al., “Does Military Aid to Police Decrease Crime?” 19 (emphasis in original).

227 Gunderson et al., "Does Military Aid to Police Decrease Crime?” 19.

228 Gunderson et al., “Does Military Aid to Police Decrease Crime?” 21.

229 Gunderson et al., “Does Military Aid to Police Decrease Crime?” 21.
} 
A 2016 paper by Federico Masera found mixed results when examining the acquisition of military equipment by individual agencies from 2000 to 2014.230 On the one hand, Masera concluded that, from 2007, when transfers of military equipment substantially increased, to 2014, each dollar per capita of military equipment was associated with a decline in violent crime by about 6.4 percent. ${ }^{231}$ Masera estimated that the violent crime rate between 2007 and 2014 decreased by 18.3 percent, but would have dropped by only 7.2 percent without the 1033 program. ${ }^{232}$

Masera did find, however, that there was some displacement of violent crime to surrounding areas, with the violent crime rate increasing by 0.5 per 1,000 persons in what he described as a "commuting zone" adjoining the jurisdiction of individual agencies. Decisions about acquiring military equipment at the agency level do not take this effect into account, which Masera describes as resulting in the "overmilitarization" of individual agencies. Masera's study also found that each dollar per capita increase in military equipment was associated with an increase of killings by police of .08 per 100,000 persons, leading him to conclude that "the militarization of the police can explain all the recent increases in police killings" in the area he studied.233

Several additional studies show mixed results or cast doubt on the effectiveness of material militarization. One 2017 study analyzed state-level purchases of military equipment from January 1991 to September 2015.234 It found that purchases of military clothing reduced assaults on police officers by 5.3 percent for each 100 purchases and armor reduced assaults by 7.6 percent per 100 purchases. The authors did not find any statistically significant effect of purchases of weapons. However, every 100 purchases of operational equipment - including cameras, night-vision goggles, audiovisual technology, disposal robots, spotlights, and mine detectors - increased the rate of assaults on officers by 4.6 percent. $^{235}$

This study suggests that the effect of clothing and armor in reducing assaults lends some support to the view that "the appearance an officer gives off is the most important factor influencing one's decision to aggress." 236 The effect of operational equipment in increasing assaults, the authors speculated, could reflect citizen resentment of infringement on privacy and "growing discontent with police and their use of militarygrade equipment." 237 Research by Mummolo provides some support for this thesis. He

\footnotetext{
230 Masera, Bringing War Home, 14.

231 Masera, Bringing War Home, 14.

232 Masera, Bringing War Home, 22.

233 Masera, Bringing War Home, 4.

${ }^{234}$ Kevin R. Carriere and William Encinosa, "The Risks of Operational Militarization: Increased Conflict Against Militarized Police," Peace Economics, Peace Science, and Public Policy 23, no. 3 (August 2017): 1-13, https://ideas.repec.org/a/bpi/pepspp/v23y2017i3p13n5.html.

235 Carriere and Encinosa, "The Risks of Operational Militarization," 7.

236 Carriere and Encinosa, "The Risks of Operational Militarization,” 10.

237 Carriere and Encinosa, "The Risks of Operational Militarization," 11.
} 
found that militarized images of police were associated with a 3.2-point decline in the desire for more police patrols in one's neighborhood. ${ }^{238}$

Another 2017 study examined the total value of military equipment transferred to counties in Connecticut, Maine, Nevada, and New Hampshire from 2006 to 2014. 239 Controlling for relevant variables, the authors found that receiving no military equipment corresponded with 0.287 expected civilian deaths by police in a county for a given year, while receiving the maximum amount of such equipment corresponds with 0.656 deaths. "In other words," they write, "moving from the minimum to the maximum expenditure values, on average, increases civilian deaths by roughly $129 \% . " 240$ Counties that received no military equipment were estimated to have 0.068 fewer deaths than the previous year, while those receiving the maximum amount were estimated to have 0.188 more than the previous year. ${ }^{241}$

Edward Lawson Jr. constructed a militarization variable that measures the value of military equipment acquired under the 1033 program by 11,800 law enforcement agencies from the fourth quarter of 2014 through the fourth quarter of $2016 .{ }^{242} \mathrm{He}$ found that the greater the level of militarization, as measured by his variable, the higher the number of deaths at the hands of the police.

Lowande's May 2020 paper noting concern about accurate 1033 program information found that about one in five weapons are returned or destroyed within five years. "I find," he says, "that most changes in police militarization in the contemporary period are the result of weapons and equipment already in circulation, and that attrition of these weapons is common." ${ }^{243}$ He suggests that trends in militarization through this program have leveled off, perhaps because of the withdrawal of many U.S. military personnel abroad. As a result, "the operative question facing interested parties is the potential effects of policy interventions that demilitarize departments with already acquired equipment." 244

In an effort to identify the effects of such demilitarization, Lowande studied jurisdictions that returned equipment in response to the Defense Department recall during the Obama administration. He focused on a period from the second quarter of 2015 to the third quarter of 2016, which represents two quarters prior to demilitarization and two

\footnotetext{
238 Mummolo, "Militarization Fails," 9184.

${ }^{239}$ Casey Delehanty et al., "Militarization and Police Violence: The Case of the 1033 Program," Research \&

Politics 4, no. 2 (2017): 1-7, https://doi.org/10.1177\%2F2053168017712885.

${ }^{240}$ Delehanty et al., "Militarization and Police Violence," 3.

241 Delehanty et al., "Militarization and Police Violence," 3.

${ }^{242}$ Edward Lawson, Jr., "Police Militarization and the Use of Lethal Force," Political Research

Quarterly 72, no. 1 (2010-8): 177-89, https://doi.org/10.1177\%2F1065912918784209.

${ }^{243}$ Lowande, Police Demilitarization and Violent Crime, 10.

${ }^{244}$ Lowande, Police Demilitarization and Violent Crime, 10.
} 
quarters after it ended. Lowande found that the data indicate that there was little evidence that demilitarization had significant impacts on violent crime or officer safety. ${ }^{245} \mathrm{He}$ acknowledges that his study is limited to the recall of certain types of military equipment under a particular government program, and with regard to several hundred police departments. It thus does not purport to establish the effects of demilitarization in general. Nonetheless, he concludes that his research suggests that there would be little risk from reducing the amount of military equipment that is held by police departments. ${ }^{246}$

\section{Summary}

Research indicates that SWAT teams are now regularly used in situations outside the emergency situations for which they were originally created. A large percentage of these operations involve forcible entries for drug searches. While there have been highprofile incidents resulting in deaths, the very limited data that are available suggest that this occurs infrequently. Nonetheless, as videos of these operations vividly attest, forcible entries are extremely violent paramilitary intrusions that always carry the risk of exchanges of gunfire. ${ }^{247}$ In addition, a large percentage of these operations take place in minority communities. Given the limited use of firearms and low number of deaths during SWAT operations, it bears asking whether SWAT units are often used in situations where the risk is no greater than what a regular officer would face.

The lack of detailed information on SWAT team operations makes it difficult to assess their effectiveness, but the few studies that exist cast doubt on their long-term effectiveness. Requiring more detailed information about SWAT deployments would be an important step in helping to ensure that these units are used only in genuinely high-risk situations when the use of regular police is not sufficient.

The percentage of law enforcement agencies acquiring military equipment from the Department of Defense has been increasing since the creation of the 1033 program (although this represents only one source of such equipment, and so understates the larger trend). Most research on the impact of acquiring military equipment indicates it has little effect on crime or attacks on police, and some find that it is positively correlated with killings by police. In addition, one study finds that acquisition of combat equipment is correlated with a minority population, while another finds acquisition of military vehicles is associated with residential segregation. More work on the effects of material militarization will be necessary, however, to take into account recent refinements in available data that the Lowande paper describes. Despite the limited research in this area, it is striking that existing studies provide little evidence that material militarization has any effect on crime.

${ }^{245}$ Lowande, Police Demilitarization and Violent Crime, 8.

${ }^{246}$ Lowande, Police Demilitarization and Violent Crime, 10.

247 See, for instance, the video in, Sack, "Door-Busting Drug Raids Leave a Trail of Blood." 
As with cultural militarization, the effect of increasing reliance on military tactics and equipment on crime is not the only consideration in assessing this trend. The combined effect of these two dimensions can result in situations in which police officers who are equipped with military-grade weapons confront those they regard as outsiders especially members of minority communities - who are presumed to pose a threat. The resulting risk is a steep price to pay for reducing crime in any democratic country.

Even when operations do not result in the use of force, the prominent display of weapons and use of military tactics highlight the possibility that it may be used. As the next section discusses, this communicates a distinct message about the relationship between the police and the community.

\section{THE SYMBOLIC DIMENSION OF MILITARIZATION}

Both material and cultural militarization have a symbolic dimension that goes to the heart of the relationship between the state and its citizens. Focusing on this dimension directs attention to how police practices and equipment are perceived by communities. In its symbolic dimension, militarization puts force in the foreground rather than the background, reversing a basic assumption about the police in a liberal democracy.

Peter Manning emphasizes the symbolic dimension of police operations by invoking the perspective of dramaturgy: a "way of seeing, using a theatrical metaphor to explore how the communication of messages to an audience conveys information and creates impressions that shape social interaction." 248 This enables us to see that "[p]olicing is at least in part a representation to which we look for the meaning of events. It is thus a translating device, a means to both amplify and reduce our sense of the fearful, the safe, the orderly, the risky, and the attractive."249

Police encounters with individuals are therefore not simply physical interactions but performances that help normatively order the social world. As Manning observes, they are means by which honor and shame are distributed among different members of society. ${ }^{250}$ This reflects the authority of the police as state agents who celebrate and condemn behavior, so that encounters between police and individuals are "[d]ramas of control that communicate and affirm social norms." 251 Understanding police operations as dramatic performances illuminates that both material and cultural militarization have significance that goes beyond their physical consequences.

\footnotetext{
248 Peter K. Manning, Policing Contingencies (Chicago: University of Chicago Press, 2010), 4. See also, Peter K. Manning, "Drama, the Police, and the Sacred," in Policing: Politics, Culture, and Control, ed. Tim Newburn and Jill Peay (London: Bloomsbury-Hart Publishing, 2012), 173.

${ }^{249}$ Manning, Policing Contingencies, 17.

250 Manning, Policing Contingencies, 21.

251 Manning, Policing Contingencies, 21.
} 
With regard to material militarization, wearing military gear and brandishing military weapons is a performative display that communicates that the threat posed by those whom an officer confronts is grave enough that it may require police to respond with the type of intensive force that the military is authorized to use. These displays occur often in African American communities, and, as events in Ferguson and following the death of George Floyd indicate, in response to demonstrations about police use of force against African Americans. ${ }^{252}$ As a result, the police can convey to African Americans that they are outsiders who should fear the police, rather than citizens who should look to it for protection. Furthermore, this communicates to the larger public that African Americans are not fellow citizens who are worthy of respect, but outsiders who warrant suspicion. In this respect, as I have suggested, police displays of military weapons and tactics resemble a military show of force that is designed both to intimidate an adversary and reassure citizens that the government stands ready to protect them.

A joint report released by the Department of Justice and the Institute for Intergovernmental Research after demonstrations in Ferguson underscored the symbolic impact of police tactics and equipment. As the report stated, "The decisions to deploy tactical officers, to use law enforcement military dress and appearance, to use military tactics (such as overwatch), and to use materiel ... all contributed to the image of militarization." 253 The report said that police use of armored vehicles, for instance, "stirred the emotions of demonstrators" and caused them to feel fear, anger, and intimidation simply because of the vehicle's presence. ${ }^{254}$ Members of the community described these as "tanks" and said that it "looked like the police were invading." 255 Similarly, having a sniper prominently in view to monitor threats created fear among peaceful demonstrators. ${ }^{256}$

The report reflected an understanding of the symbolic dimension of militarization. It emphasized the importance of keeping paramilitary units and military equipment out of sight until it is necessary to use them. ${ }^{257}$ Similarly, it said that "armored vehicles should not be visible to protesters except in narrowly defined circumstances, for example when shots are fired and in some active shooter situations."258

\footnotetext{
252 Niraj Chokshi, "Militarized Police in Ferguson Unsettles Some; Pentagon Gives Cities Equipment," Washington Post, Aug. 14, 2014, https://www.washingtonpost.com/politics/militarized-police-in-fergusonunsettles-some-pentagon-gives-cities-equipment/2014/08/14/4651f670-2401-11e4-86ca6f03cbd15c1a story.html; and Andrew W. Lehren et al., "Floyd Protests Renew Debate About Police Use Of Armored Vehicles, Other Military Gear," NBC News, June 20, 2020, https://www.nbcnews.com/news/usnews/floyd-protests-renew-debate-about-police-use-armored-vehicles-other-n1231288. ${ }^{253}$ After-Action Assessment of the Police Response to the August 2014 Demonstrations in Ferguson, Missouri, U.S. Department of Justice Office, Office of Community Oriented Policing Services, 2015, https://www.policefoundation.org/wp-content/uploads/2018/08/After-Action-Assessment-of-the-PoliceResponse-to-the-August-2014-Demonstrations-in-Ferguson-Missouri.pdf.

${ }^{254}$ After-Action Assessment, 55.

${ }^{255}$ After-Action Assessment, 55.

${ }^{256}$ After-Action Assessment, 56.

${ }^{257}$ After-Action Assessment, 59.

${ }^{258}$ After-Action Assessment, 60.
} 
Material militarization has symbolic significance in that it communicates a departure from normal expectations regarding the role of police and how they use force. Good police work is "the craft of handling trouble without resort to coercion." 259 This is reflected in the rules governing the use of force by law enforcement officers. They require that force be used only as a last resort, that the amount of force be proportionate to the threat that it aims to address, and that lethal force be used only to protect life.

These standards imply that the role of the police is as members of the social contract who are authorized to preserve peace and protect fellow citizens from harm. This requires treating citizens with respect, attempting first to use persuasion to restore order and prevent harm. Police always have the authority to use force, but force is in the background as a last resort. This reflects a working presumption that individuals are members of the social contract rather than people who threaten it.

Shows of force by the police through measures such as SWAT team raids and displays of military equipment move force into the foreground. They can communicate that police regard the community as a threat to the social contract and that police are ready to use force to meet this threat. Even if they do not use force, police confront the community as agents of the state prepared to fight its enemies.

Lieblich and Shinar emphasize how problematic it can be when military-style operations are used outside of emergencies and become normalized. ${ }^{260}$ When militarization becomes more common, the presumption that individuals from certain communities are outsiders who pose a threat can become a background assumption of daily life. ${ }^{261}$ The use of military weapons and tactics communicates to communities subject to them, as well as to the larger public, that certain individuals and groups pose a threat to the public that is more urgent than the need to control ordinary criminals through conventional policing methods.

Cultural militarization also has a symbolic dimension. Tyler and his colleagues suggest that aggressive preventive policing expresses an adversarial rather than collaborative relationship, which places certain persons outside the community. ${ }^{262} \mathrm{Epp}$, Maynard-Moody, and Haider-Markel make a similar point in their study of traffic stops. The goal of investigatory stops, they argue, is to see "whether a person is up to no good," which can prompt officers to act on the basis of implicit stereotypes. ${ }^{263}$ Such practices violate the

\footnotetext{
259 Robert Reiner, "Policing and the Police" in The Oxford Handbook of Criminology, 2nd ed., ed., Mike Maguire, Rod Morgan, and Robert Reiner (Oxford: Oxford University Press, 1997), 997-1049, 1008.

260 Lieblich and Shinar, "Case Against Police Militarization," 108.

261 Lieblich and Shinar, "Case Against Police Militarization,” 112.

262 Tyler, Jackson, and Mentovich, “Consequences of Being," 617.

263 Epp, Maynard-Moody, and Haider-Markel, Pulled Over, 124.
} 
principle that "people should be treated as equal, respected members of society and not as second-class outsiders."264

As Paul Butler has observed, stop-and-frisk policing "causes many men of color to hate the police, and makes them less willing to engage with the government in any way, because the primary manifestation of the government in their lives - the police - treats them with such contempt."265 James Forman Jr. describes the experience of students at a charter school in Washington, D.C., that he helped establish:

As young people in a high-crime community, they were automatically viewed as potential enemies. This fact points to one of the most destructive aspects of modern policing. Although officers recognize some segments of the community - the shopkeepers, the pastors, the elderly grandmothers - as law-abiding citizens, they regard most neighborhood residents, and young people in particular, with generalized suspicion. ${ }^{266}$

Jerome Skolnick noted this tendency more than 50 years ago in his study of policing operations in "Westville":

The policeman ... develops a perceptual shorthand to identify certain kinds of people as symbolic assailants, that is as persons who use gesture, language, and attire that the policeman has come to recognize as a prelude to violence .... The patrolman in Westville, and probably most communities, has come to identify the black man with danger. ${ }^{267}$

The increase in material and cultural militarization in recent years continues a long trend in which policing is used to exercise control over African Americans who are viewed as outside the social contract and who ought, therefore, to be monitored and disciplined because of the threat they pose to the body politic. This history has generated the belief among many African Americans that the police are people from whom they need to protect themselves rather than people they can look to for protection.

There is not space here to recount this history in full, but it underscores the fact that concern about the symbolic role of material and cultural militarization in communicating a message of social control is not abstract or fanciful. That history includes a period of more than 200 years in which slave patrols in the South served as a "transitional" form of police, and in which police were used to enforce Jim Crow laws. In the North, it includes the rise of professional police forces to respond to what was regarded as the emergence of dangerous

\footnotetext{
${ }^{264}$ Epp, Maynard-Moody, and Haider-Markel, Pulled Over, 153.

265 Butler, Chokehold, 95.

${ }^{266}$ Forman, Locking Up, 155.

${ }^{267}$ Jerome H. Skolnick, Justice Without Trial: Law Enforcement in Democratic Society (New York: Wiley, 1966), $45,49$.
} 
lower classes that threatened social order. More subtly, it involved the use of policing to informally enforce patterns of racial segregation.

Slave patrols originally were part of the colonial militia but eventually became specialized forces that focused solely on enforcing state laws regulating slavery. ${ }^{268}$ These laws prohibited slaves from going beyond the boundaries of their masters' property, requiring passes in order to do. Solomon Northup's Twelve Years a Slave describes the role of patrols in enforcing these laws:

Patrollers, whose business it is to seize and whip any slave they may find wandering from the plantation ... ride on horseback, headed by a captain, armed, and accompanied by dogs. They have the right, either by law, or by general consent, to inflict discretionary chastisement upon a black man caught beyond the boundaries of his master's estate without a pass, and even to shoot him, if he attempts to escape. ${ }^{269}$

Patrols thus explicitly sought to prevent African Americans from attempting to become free citizens, and to return them to their status as lower forms of life not fit for participation in the larger community.

Furthermore, slave patrols were authorized to address perceived threats from slaves that went beyond their attempted escape. These included criminal acts of resistance such as theft, crop destruction, arson, and poisoning. Most ominous was the threat of slave revolts. ${ }^{270}$ Because of the need to discipline and regulate every aspect of slaves' lives to forestall such threats, "[t]he hallmark of slave patrolling was the belief that every facet of black life was suspect, warranting aggressive police intervention and criminal investigations."271 This involved unrestrained search and seizures of slave quarters and immediate physical punishment for even minor infractions. ${ }^{272}$

During the Jim Crow-era in the South, police reinforced a racial hierarchy by enforcing segregation and vagrancy and loitering statues known as the "Black Codes."273 Sandra Bass notes that "African-Americans were also prohibited from engaging in a broad range of 'disorderly offenses' such as using insulting gestures of language, engaging in

\footnotetext{
268 Philip L. Reichel, "Southern Slave Patrols as a Transitional Police Type," American Journal of Police 7, no. 2 (1988): 51-78, https://www.ncjrs.gov/App/Publications/abstract.aspx?ID=116023. See also, Sally E. Hadden, Slave Patrols: Law and Violence in Virginia and the Carolinas (Cambridge, MA: Harvard University Press, 2003); Stanley W. Campbell, Slave Catchers: Enforcement of the Fugitive Slave Law, 1850-1860 (Chapel Hill: University of North Carolina Press, 1970); Larry H. Spruill, "Slave Patrols, 'Packs of Negro Dogs' and Policing Black Communities," Phylon 53, no. 1 (Summer 2016): 42-66, https://www.jstor.org/stable/phylon1960.53.1.42; and Sandra Bass, "Policing Space, Policing Race: Social Control Imperatives and Police Discretionary Decisions," Social Justice 28, no. 1, (Spring 2001): 156-76, https://www.jstor.org/stable/29768062.

${ }^{269}$ Solomon Northrup, Twelve Years a Slave (Baton Rouge: Louisiana State University Press, 1977), 180-81.

270 Reichel, "Southern Slave Patrols," 55.

${ }^{271}$ Spruill, "Slave Patrols," 49.

272 Spruill, "Slave Patrols," 48.

${ }^{273}$ Bass, "Policing Space, Policing Race," 160.
} 
malicious mischief, preaching the Gospel without a license, or taking on employment other than as farmers or servants without paying an annual tax."274

The sentiment behind such laws was expressed well by the editor of the Lynchburg Virginian in 1865:

[S]tringent police regulations may be necessary to keep [freedmen] from overburdening the towns and depleting the agricultural regions of labor. The civil authorities also should be fully empowered to protect the community from this new imposition. The magistrates and municipal officers everywhere should be permitted to hold a rod in terrorem over these wandering, idle, creatures. Nothing short of the most efficient police system will prevent strolling, vagrancy, theft, and the utter destruction of our industrial system."275

Police enforced these laws by using violence and by failing to interfere when white citizens used violence against African Americans. Images of blacks as unusually violent and prone to crime legitimized arrests and punishment for relatively minor offenses as preventive measures to exercise control over the black population.

The emergence of professional police in the North was the product of several factors, but many scholars suggest that it was a response less to actual criminal trends than to perceptions of rising social disorder. In this sense, it reflected more of an emphasis on social control rather than crime control. ${ }^{276}$ Those who needed to be controlled were regarded as members of the "dangerous classes," who consisted mainly of "the poor, foreign immigrants, and free blacks." 277 This led to preventive activities to surveil such people, prominently inserting the police into their everyday lives. The scope of such measures is expressed in an 1885 article explaining the need for "Confinement of Habitual Drunkards," and "Police control of Vagrants and Beggars." 278

In addition, as racial discrimination resulted in increasingly segregated residential patterns, police served to reinforce these spatial boundaries. ${ }^{279}$ This included treating

\footnotetext{
274 Bass, “Policing Space, Policing Race," 160.

275 Lynchburg Virginian, June 12, 1865, quoted in Spruill, 59.

276 See, for example, Randall G. Shelden and Pavel V. Vasiliev, Controlling the Dangerous Classes: A History of Criminal Justice in America, 3rd ed. (Long Grove, IL: Waveland Press), 59-102; Robert J. Lundman, Police and Policing: An Introduction (New York: Holt, Rinehart \& Winston, 2010), 29; and Gary Potter, "The History of Policing in The United States," Police Studies Online, Eastern Kentucky University, https://plsonline.eku.edu/insidelook/history-policing-united-states-part1\#: : text=Written $\% 20$ by $\% 20$ Dr.\%20Gary $\% 20$ Potter $\% 20$ The $\% 20$ development $\% 20$ of,which $\% 20$ is $\% 20$ calle d\%20\%22The\%20Big\%20Stick\%E2\%80\%9D\%20\%28Spitzer\%2C\%201979\%29.

277 Potter, "History of Policing in the United States," 3.

278 C. G. Tiedeman, "Police Control of Dangerous Classes, Other than by Criminal

Prosecutions," American Law Review 19, no. 4 (July/August 1885): 547-70.

279 Bass, "Policing Space, Policing Race," 161-64. On the role of various policies that produced such segregation, see, Sheryll Cashin, The Failures of Integration: How Race and Class Are Undermining the
} 
blacks in predominately white neighborhoods as objects of suspicion and potential harassment for venturing beyond their appropriate "place." 280 As Bass observes, "The inability to live beyond the boundaries of the ghettos and to move freely within the city without fear of police harassment severely restricted the civil liberties of AfricanAmericans." 281

In these ways,

The fact that the legal order not only countenanced but sustained slavery, segregation, and discrimination for most of our nation's history and the fact that the police were bound to uphold that order set a pattern for police behavior and attitudes toward minority communities that has persisted until the present day. ${ }^{282}$

Aside from their physical impacts, material and cultural militarization therefore have powerful symbolic significance by signaling that racial and ethnic minorities, and especially African Americans, are "objects of law enforcement and social control rather than ... citizens entitled to civil protections." 283

\section{CONCLUSION}

Police militarization has become a prominent subject of debate in recent years. SWAT team no-knock raids and police deployed with military equipment are naturally targets of criticism because they can increase the risk of violence against citizens. A deeper concern, however, is that they impose barriers between the police and the communities they serve that reflects the cultural dimension of militarization.

The thousands of local police departments across the country necessarily vary with respect to the dimensions of militarization I have described. Nonetheless, larger trends suggest that it may be important for communities to rethink which measures will best provide public safety. As a practical matter, research indicates that the use of military weapons, gear, and tactics does not serve to make the public safer. On a more fundamental level, the use of measures designed to protect citizens from external threats posed by enemies of the nation are not appropriate in protecting against internal threats to public order. In particular, increasing police militarization risks transforming law enforcement in minority communities into national security operations, with corresponding greater authority to use force and restrict liberty. Aside from the concrete harms that this can inflict, it extends the national security paradigm into a domestic setting in which it should

American Dream (New York: PublicAffairs, 2005); and Douglas S. Massey and Nancy A. Denton, American Apartheid: Segregation and the Making of the Underclass (Cambridge, MA: Harvard University Press, 1993). 280 Bass, "Policing Space, Policing Race," 163.

${ }^{281}$ Bass, "Policing Space, Policing Race," 162.

${ }^{282}$ Hubert Williams and Patrick V. Murphy, "The Evolving Strategy of Police: A Minority View," Perspectives on Policing, no. 13, (January 1990): 2, https://www.ncjrs.gov/pdffiles1/nij/121019.pdf.

283 Bass, "Policing Space, Policing Race," 163. 
not apply. In this respect, police militarization threatens the integrity of the very concept of national security.

Sir Robert Peel, regarded as the founder of the modern professional police force in London in 1829, adopted as one of his principles the following: "The police are the public and the public are the police."284 Militarization in its various dimensions undermines this principle. In both tangible and symbolic ways, it treats certain members of society as outside the social contract, people who have to be managed by external force. This is counter-productive for law enforcement because it neglects the important role that communities play in creating and sustaining social order. More importantly, by treating them as suspects and enemies, it deprives members of these communities the status of full citizenship.

Mitt Regan is McDevitt Professor of Jurisprudence at Georgetown Law Center and a senior fellow at the Stockdale Center for Ethical Leadership at the United States Naval Academy. This article expands on a presentation at the 2016 McCain Conference on Civil-Military Relations at the U.S. Naval Academy sponsored by the Stockdale Center.

Acknowledgements: I'm grateful for very helpful comments on the article from Paul Butler, Jovana Davidovic, Brian Kamoie, Sherri Keene, Tiffany Jeffers, Christy Lopez, David Luban, Seumas Miller, Deborah Pearlstein, Scott Phillips, Mara Revkin, Nancy Sachs, and two anonymous reviewers for the Texas National Security Review.

284 "The Principles of Good Policing," Civitas, accessed Dec. 8, 2020, http://www.civitas.org.uk/research/crime/facts-comments/principles-of-good-policing/. 